OECD Economics Department Working Papers No. 86

Modelling Wages and Prices for the Smaller OECD Countries

\section{Kenichi Kawasaki,}

Peter Hoeller,

Pierre Poret 


\section{OECD \\ DEPARTMENT \\ OF ECONOMICS AND STATISTICS}

\section{WORKING PAPERS}

No.86 MODELLING WAGES AND PRICES FOR THE SMALLER OECD COUNTRIES

by

Kenichi Kawasaki, Peter Hoeller and Pierre Poret

October 1990

OCBDE

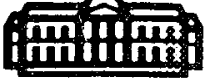

(OESD 
GENERAL DISTRIBUTION

ECONOMICS AND STATISTICS DEPARMWHIT

\title{
HORKIMG PAPERS
}

\begin{abstract}
This series of Working Papers is designed to make available, to a wider readership, selected studies which the Department has prepared for use within OECD. Authorship is generally collective, but main individual authors are named. The papers are generally available in their original language, English or French, with a summary in the other.

Comment on the Papers is invited, and may be sent to OECD, Department of Economics and Statistics, 2 rue André Pascal, 75775 Paris Cedex 16, France. Additional copies of the Papers on a limited basis can be forwarded on request.
\end{abstract}


This paper presents work on wage/price blocks for the smaller OECD countries which has been implemented in OECD's world econometric model, INTERLINK. The paper discusses theoretical, statistical and practical aspects of the estimation of business sector wage equations and five domestic demand deflators. It also presents a variety of diagnostic simulations in order to evaluate overall model properties.

Ce papier présente le bloc prix-salaires des petits pays du modèle mondial de 1'OCDE, INTERLINK. Le papier examine les aspects théoriques, statistiques et pratiques des équations, estimées pour le taux de salaire du secteur des entreprises et cinq déflateurs de la demande intérieure. II présente aussi un ensemble de simulations destinées à évaluer les propriétés variantielles globales du modèle. 
No.86 MODELLING WAGES AND PRICES FOR THE SMALLER OECD COUNTRIES

by

Kenichi Kawasaki*, Peter Hoeller and Pierre Poret

General Economics Division

October 1990

* Mr. Kawasaki is now with the Economic Planning Agency, Japan.

The authors would like to give special thanks to Martine Durand, now in Country Studies I Division; her earlier work on wage equation estimation is reflected in the paper, in particular in some of the equations reported in Table 2. They would like to acknowledge comments and suggestions by Andrew Dean, Robert Ford and Pete Richardson. They are also grateful for efficient research assistance by Valérie Barca, Anick Lotrous and Chantal Nicq and for expert typing by Jackie Gardel. 
TABLE OF CONTENTS

Page

INTRODUCTION

I. THE STYLISED MODEL OF WAGE AND PRICE BEHAVIOUR 7

II. WAGE AND PRICE EQUATION ESTIMATES 9

1. Testing for long-run relationships 9

2. Wage equation estimation results 10

3. Price equation estimation results 13

III. SIMULATION PROPERTIES 17

IV. CONCLUDING REMARKS 19

Notes 21

Bibliography 23 


\section{LIST OF TABLES}

1. Unit root tests

2. Aggregate wage equations

3. Natural rate of unemployment estimates

4. Indirect tax rate assumptions

5. Equations for domestic demand deflators

6. Wage/price block simulations

7. Single-country effects of an increase in government expenditure with fixed nominal interest rates and exchange rates

8. Single-country effects of a percentage point decrease in short-term interest rates with floating exchange rates and fixed real government expenditures

9. Single-country effects of a 10 per cent effective depreciation with fixed nominal interest rates and fixed real government expenditures

10. Comparison of simulation properties between large and smaller countries 


\title{
MODELLING WAGES AND PRICES FOR THE SMALLER OECD COUNTRIES
}

\author{
INTRODUCTION
}

Developments in wage and price inflation are of central importance in macroeconomic analysis and forecasting. A complete set of wage and price equations for the major seven OECD countries was estimated and implemented in OECD's international model INTERLINK some time ago (see Stiehler, 1987). This paper now reports similar work for the smaller OECD countries.

The estimation of wage equations for the smaller countries adopts the same approach as for the large countries. The specification follows a standard approach to wage-setting where the long-run equilibrium for real wages is reached when labour markets operate at the "natural rate of unemployment". Disequilibrium forces include deviations of actual from trend productivity, terms-of-trade effects and sluggish adjustment of wages to recent price developments. As for prices, domestic demand deflators are modelled as a mark-up over unit costs with mark-ups being allowed to fluctuate cyclically. In the context of the INTERLINK model monetary policy influences inflation through various channels. There are relatively direct effects via exchange rates and import prices and less direct effects which work through changes in labour and goods market tightness.

Part I of this paper presents the stylised facts about the wage/price block and its relation to other parts of the model, especially monetary policy instruments. Part II discusses the specification for the wage and price equations and presents estimation results. It also includes wage/price block simulations. Part III presents full model simulation results. The final section includes some suggestions for future work. 


\section{THE STYLISED MODEL OF WAGE AND PRICE BEHAVIOUR}

At the centre of the wage/price block is a standard theoretical model of wage determination: the rate of change of wages $(w)$ is indexed to past $(p)$ and expected $\left(p_{e}\right)$ inflation and productivity growth in the short $(q)$ and long run $\left(q_{n}\right)$. The effects of labour-market disequilibria on wage growth are captured by the deviation of the rate of unemployment (U) from the natural rate $\left(U_{n}\right)$. Furthermore, wage rates are assumed to react to differences in consumer ( $p$ ) and producer price inflation (pgdp).

$$
w=a_{1} p+\left(1-a_{1}\right) p_{e}+a_{2}\left(U-U_{n}\right)+a_{3} q+\left(1-a_{3}\right) q_{n}+a_{4}(p-p g d p)
$$

Unitary elasticities of wages with respect to prices and productivity ensure first that the wage equation is homogeneous in price inflation and, second, that real wages will grow in line with labour productivity in the absence of a labour-market gap and changes in consumer relative to output prices. The wage equation could also be estimated in levels using an errorcorrection term. This would ensure, in addition, that income shares would return to "normal" levels in long-run equilibrium.

Assuming constant returns to scale and oligopolistic price-setting, changes in domestic demand deflators $(p)$ are determined as a mark-up over unit cost changes in the long run. Cost elements include smoothed changes in unit labour costs (1c), capital costs (cc) and import costs (pm). Profit margins are allowed to depend positively on the rate of capacity utilisation ( $g$ ), reflecting, for instance, the difference in the development of average and marginal cost over the cycle:

$$
p=a_{1} 1 c+a_{2} c c+\left(1-a_{1}-a_{2}\right) p m+a_{3} g
$$

Price inflation is stable if unit costs grow at a constant rate and excess demand is zero. An error-correction term between price and cost levels could be added to the specification; this would ensure constant profit margins in the long run. An important characteristic of the wage/price block is the 
inter-connection of equilibria in the goods and labour markets. As capacity utilisation in the goods market is measured using maximum employment given by the "natural" rate as derived from the wage equation estimates, stable wage and price inflation is achieved only if both markets are in equilibrium at the same time (Torres and Martin, 1990).

Monetary policy is important in shaping inflationary developments, but monetary aggregates do not directly affect wage and price developments. In the context of the INTERLINK model, expansionary monetary policy leads to a reduction in nominal, and, given sluggish price adjustment, real short-term and long-term interest rates. Real interest rates enter the consumption and housing equations and alter demand for labour and capital inputs. In addition, interest-rate changes affect exchange rates, which in turn move foreign demand and trade prices. In sum, monetary policy affects demand deflators via exchange rates, import prices and capital costs and works indirectly through changes in the unemployment rate and excess demand in goods markets. An overview of the interaction between the different blocks of INTERLINK involved in this process is given in Richardson (1987 and 1988).

Whether simple models of aggregate wage and price behaviour as outlined above are an accurate description of major aspects of macro-relationships and of use for policy analysis is subject of recurrent controversy. If expectations are formed rationally, no policy trade-offs exist, even in the short run, as agents fully take account of monetary policy. Only imperfect information and adjustment costs can cause deviations from equilibrium. Furthermore, use of estimated equations for policy analysis will be faulty if expectations are not independent of policy rules (Lucas, 1976). Although the new classical critique of the Phillips curve has been influential, research on the microeconomics of sluggish adjustment as optimising behaviour, has given new credence to the augmented Phillips-curve approach adopted in this paper (1). 


\section{WAGE AND PRICE EQUATION ESTIMATES}

\section{Testing for long-run relationships}

Whether the wage and price equations should be specified in terms of levels or growth rates is an important modelling issue. The answer depends on the existence of a stable long-run "equilibrium" level relationship. If such an equilibrium exists, the dynamics of an equation specified in growth-rate terms will be misspecified because the information that the dependent variable tends to revert to some trend level in the long run will be lost. On the other hand, if no stable "normal" level can be found, an equation with an errorcorrection mechanism will lead to spurious estimates.

The existence of a long-run equilibrium relationship can be examined by testing for "stationarity" of the series -. a series being defined as stationary when innovations do not permanently affect the long-run value. This issue is examined using unit-root tests. In principle, the hypothesis that the so-called wage (price) target is non-stationary is tested, or more specifically, whether the target is correlated with its one-period-lagged value with a coefficient not inferior to unity. In the case of a unitary coefficient, any shock to the variable will persist indefinitely. Table I gives a formal definition of stationarity and a detailed description of the tests.

The wage target was defined as the ratio of real consumption wages to current labour efficiency, assuming a unitary elasticity of wages with respect to prices and productivity. This ratio differs somewhat from usual definitions of the labour share as consumer prices are used instead of the output deflator, non-wage labour costs are excluded and labour productivity is adjusted for the effect of capital-labour substitution. Except for Ireland and Switzerland the tests unambiguously fail to reject the null hypothesis of non-stationarity, thus suggesting that there is no stable long-run equilibrium in terms of levels and justifying a specification of the wage equations in growth rate terms (Table 1, line (1)). 
The price target selected for the test of mean reversion of profit margins is the ratio of the private consumption deflator to total costs (a weighted average of labour, capital and import costs). These cost components form the basis of the mark-up setting process. Tests suggest that the mark-up is stationary for Denmark, Finland, the Netherlands and Switzerland (Table 1, line (2)), thus supporting a specification in terms of levels for those countries. There is much less support in the data for stationarity of the mark-up term for the other countries. However, the cost weights have been imposed and a free estimation would have probably improved the stationarity of the mark-up term. It is also possible that the time to revert to trend exceeds the relatively short sample-period horizon used for these tests.

However, a feature of the results is that the price target is closer to stationarity than the wage target as the test statistics in Table 1 are generally higher for the former than for the latter. Thus, the inclusion of other costs than labour cost leads to a more stable mark-up than it would be if simply defined as a standard profit share. As longer-run changes in profit margins are also difficult to justify in simulations, the price equations were specified in levels.

\section{Wage equation estimation results}

The estimation of wage equations adopted here follows the approach summarised in Coe and Gagliardi (1985) and Coe (1985). That work focused on wage equations for the major seven OECD countries and four smaller OECD countries - Australia, Austria, the Netherlands and Switzerland.

The dependent variable in the equations is the growth rate of business sector wages and salaries per employee ( $w$ ) (2). It is related to a moving average of past changes in the private consumption deflator ( $p$ ) and an activity variable (U). The activity variable is represented by the unemployment rate except for the case of Switzerland where a measure of employment is used. In addition, tests are carried out for short-run productivity ( $q$ ) and producer price effects ( $p, p g d p)$. The natural rate of unemployment and trend productivity are not modelled explicitly (see below), but form part of the constant: 


$$
w=a_{0}+a_{1} p-a_{2} U+a_{3} q+a_{4}(p-p g d p)
$$

The equations chosen for implementation in INTERLINK are presented in Table 2. The selection criteria used included goodness of fit, recent tracking performance and the overall simulation properties of the country model. A variety of specification and other issues are reported below.

Specification of the unemployment term. Linearity of the activity term was examined for each country. A linear specification implies that unemployment has the same impact on wage increases regardless of its level, while in the inverse case the effect of unemployment on wage increases is lower the higher the rate of unemployment. The use of the $10 \mathrm{~g}$ of the unemployment rate implies that a given percentage change in the unemployment rate has the same effect regardless of its level. A linear version of the activity variable was chosen for Australia, Belgium, Greece, New Zealand and Switzerland, the inverse for Norway and Sweden and the logarithmic version for Austria, Denmark, Finland, Ireland, the Netherlands and Spain (3).

Inflation. Over a longer stretch of time wages are likely to follow inflation rates closely - o otherwise real wages would change indefinitely in response to changes in inflation. Coe (1985) showed that the estimated coefficients were insignificantly different from unity for the eleven countries in his sample. As homogeneity is also an important model property for large nominal shocks, a unitary coefficient of wage inflation with respect to the moving average of past changes in the consumption price deflator was imposed. The only exceptions are Australia and Spain, although homogeneity will be imposed for these two countries in the next round of estimation.

Adaptive expectations are assumed (4). Coe (1985) tested several forms of forward-looking expectations formation and arrived at the conclusion that such a specification did not improve estimates over specifications using current and past inflation (5). Furthermore, model-consistent expectations can not yet be generated in INTERLINK.

The role of producer prices. An output price effect, in the form of differences in growth rates between the business sector output and consumption 
deflators has also been tested. While wage rates relative to consumer prices are relevant for labour supply, total compensation deflated by output prices is important for labour demand of employers. The weights between consumption and output price deflators are likely to depend on the slopes of the labour demand and supply curves, but could also reflect the fact that bargaining takes account of profitability in the business sector. The output price effect is large in Austria, Switzerland and New Zealand and still sizeable in Belgium, Greece, Ireland and Norway. Following an approach more akin to the Scandinavian model of wage determination, the output price deflator is replaced by the export price deflator in the case of Sweden (6).

Productivity effects. Current and lagged effects of business sector productivity growth were tested for all countries and, where significant, retained in the equations. Cyclical movements in productivity were found to have a significant effect in Belgium, Denmark, Finland, Greece, New Zealand, Norway, Spain and Switzerland. The short-run productivity effect captures the cyclical variability of bonus and overtime payments. In some countries the results are consistent with forms of bargaining behaviour which take explicit account of recent productivity developments.

The "natural" rate of unemployment. An important question for macroeconomic policy is whether current labour-market conditions are likely to lead to wage moderation or accelerating wage inflation. As argued above (equation [1]), this will largely depend on the difference between the current rate of unemployment and the natural rate of unemployment. In steady-state, output and consumer prices and wages grow at the same rate, the unemployment rate is at its natural rate and productivity grows at its trend rate. Taking these conditions and rearranging equation [3] gives the following expression for the natural rate $\left(U^{*}\right)$ :

[4a] $U^{*}=\left(a_{0}-\left(1-a_{3}\right) q_{n}\right) / a_{2}$ for the linear case;

[4b] $U^{*}=\exp \left[\left(a_{0}-\left(1-a_{3}\right) q_{n}\right) / a_{2}\right]$ for the logarithmic case;

[4c] $U^{*}=a_{2}\left[\left(1-a_{3}\right) q_{n}-a_{0}\right]$ for the inverse specification.

Natural rates implied by the Phillips-curve estimates are shown in Table 3. As the calculation of the natural rate depends on the development of 
trend labour productivity growth, the numbers are shown for sub-periods. In most of the smaller countries, natural rates have drifted upwards since the $1960 \mathrm{~s}$ as labour productivity growth has slowed down. After a period in which actual unemployment rates have been much higher than natural rates in the early 1980s, a period coinciding with wage moderation, unemployment rates are now close to the estimated natural rates in Austria, Sweden, Finland and Switzerland. In some countries, for instance Spain and Ireland, current unemployment rates are still far above the estimated natural rate (7). It needs to be stressed that such estimates of the natural rate provide only a rough guide as to when inflationary pressures stemming from the labour market may arise. Large confidence intervals around these estimates are likely to apply, due to imprecise coefficient estimates and potential misspecification. In particular, the calculations here assume that the only source of change of the natural rate stems from changes in trend productivity. Hence the growth of minimum wages, changes in the unemployment benefit replacement ratio and in unionisation, all factors which are thought to affect the natural rate of unemployment have not been taken into account.

\section{Price equation estimation results}

Equations for five domestic demand deflators have been estimated: the deflator for private consumption, for government non-wage consumption, for government investment, for business non-residential investment and for housing investment. Deflators for exports and imports had been estimated earlier (Herd, 1987). The deflator for inventory changes is exogenous for the smaller country models while final and total domestic demand, GDP and business sector output deflators are calculated by identity.

There is a rich choice of right-hand-side variables and specifications. The initial work on the price blocks was therefore confined to testing specifications for a limited number of countries. The choices reviewed and the findings of this experimental stage are summarised below without showing estimation results:

a) Indirect taxes. Proper modelling of price developments should rely on time series of net indirect tax rates by demand component. These are 
available only for Denmark. For the other countries, information is available only for individual years from input-output tables, which are often out of date and not aggregated properly from the point of view of INTERLINK. Aggregate net indirect tax rates were therefore used for those deflators where the amount of taxation was significant. For instance, in countries with a VAT system the aggregate indirect tax rate for the private consumption deflator was used, but no indirect tax rate was applied to the business investment deflator. These assumptions, based on the available information about tax systems and input-output tables, are shown in Table 4.

b) Domestic costs. Labour and capital cost are scaled by potential business sector output rather than actual output so as to smooth cyclical cost developments. The effect of real interest rates on capital costs has been reduced from its standard INTERLINK definition in order to better reflect the financial capital/output ratio. While labour and capital cost shares in the price equations were initially estimated, this often yielded unsatisfactory results. Large capital shares, for instance, produce counter-intuitive results in interest-rate simulations. The shares were therefore imposed at their historical values in the follow-up work.

c) Import costs. Import costs have not been split into components, for instance, into energy and non-energy parts. Experimentation showed that this would affect estimation results little. Among large energy producers, a domestic energy component is implemented only for the Netherlands, since no suitable data are available for Norway. Experiments with moving weights between import and domestic costs were also made. As sample periods range back only to the early 1970s, using moving weights changed results little and they were thus dropped from the equations.

d) Output gap term. For the smaller countries two gap terms are available from the INTERLINK supply block: one is the ratio of actual to "potential" output and the other the ratio of actual to "normal" output (Torres et al., 1989). The measure relating actual to "potential" output has been preferred because this measure reinforces the link between output and labour markets, as "potential" is evaluated at the natural rate of unemployment 
implicit in the wage equations. It was thus used for all the other countries. As the coefficient on the gap term was incorrectly signed or of implausible size in estimated equations for some demand deflators, it was restricted to be the same across demand deflators.

e) Error-correction term. Error correction between domestic prices and cost components might be restricted to import costs only, establishing a law of one price in the long-run, in domestic cost only, or in a mixture of both. An error-correction term in both domestic and import costs was finally selected. As the freely-estimated share of import cost was often low, especially for the business investment deflator, this coefficient was imposed using input-output table information for the different deflators. Where such information was not available, a rough estimate was made, using aggregate import shares and deflator-specific information for similar countries.

The specification chosen and estimation, results. With little variation across countries, the following equations were estimated as a simultaneous equation system. Small letters indicate growth rates of a variable and capitals indicate series in level or index form:

$$
\begin{aligned}
p= & a_{0}+\left(1-a_{1}\right)\left(a_{2} 1 c+\left(1-a_{2}\right) c c\right)+a_{1} p m+a_{3} G \\
& \left.+a_{4}\left(\left(1-a_{5}\right) \ln \left(a_{2} L C(-1)+\left(1-a_{2}\right) C C(-1)\right) / P(-1)+a_{5} \operatorname{lnPM}(-1) / P(-1)\right)\right)
\end{aligned}
$$

where $P=P_{i t} / T$, the five demand deflators excluding indirect taxes

$\mathrm{P}_{\text {it }}=$ demand deflators including indirect taxes

$\mathrm{T}=$ tax base/(tax base - indirect taxes + subsidies)

LC $=$ WSSE$^{*}($ ETBPT/QBVPT $)$, unit labour cost

WSSE $=$ compensation per employee

ETBPT = potential business sector employment

QBVPT $=$ potential business sector output

$\mathrm{CC}=\mathrm{PIB} *\left(\mathrm{XRHOR}+\mathrm{XRSCRB}+0.3^{*} \mathrm{IRLRE}\right) / 100^{*}(\mathrm{KBV} / \mathrm{QBVPT})$, capital cost

$\mathrm{PIB}=$ business sector investment deflator

IRLRE = real interest rate

$\mathrm{KBV}=$ business sector capital stock

XRHOR, XRSCRB $=$ parameters 


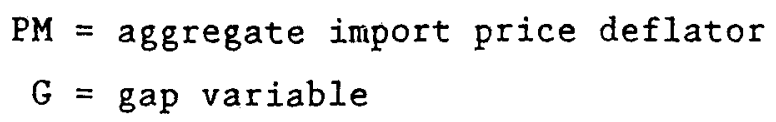

Growth rates for domestic and import costs are moving averages with different $\mathrm{lag}$ lengths between domestic and foreign costs. Demand deflators are from national sources except for the government non-wage deflator (PCGNW), which has been calculated assuming no increase in the productivity of government employees:

[6] $\quad \mathrm{PCGNW}=(\mathrm{CG}-\mathrm{CGW}) /(\mathrm{CGV}-\mathrm{CGW} / \mathrm{WRG})$

where $\quad C G=$ government consumption in nominal terms

$\mathrm{CGW}=$ government wage bill

$\mathrm{CGV}=$ government consumption in real terms

WRG = government wage rate

The government deflator in the price block is then calculated by identity using the endogenous wage component ( 8 ).

Estimation results for the domestic demand deflators are summarised in Table 5 (9). The sample periods, lag lengths for import cost and domestic cost variables and the imposed labour income share are shown in parentheses. The gap term is restricted to be the same across deflators and marked with "@" in Table 5. Imposed parameters are marked with "I".

The gap term was not significant for Belgium, Denmark, Finland, Ireland and New Zealand. A small gap coefficient was imposed for Denmark and the Belgian equation re-estimated relaxing the restriction on the gap coefficient. For the other countries the gap term coefficient lies in a range of 0.03 for Austria to 0.17 for Australia. While the small coefficients for some countries seem reasonable in the light of their openness and Australia's large coefficient seems reasonable in terms of its small share of imports, it is difficult to generalise further as many other factors are potentially important in influencing pricing decisions. For instance, industrial policies severely limiting competition were in place in New Zealand over most of the sample period (OECD, 1987). 
Estimation results for the government non-wage deflator are generally the poorest and in some cases a large number of dummy variables was used to arrive at reasonable equations. Coefficients were also imposed in the few equations where the error-correction coefficient was wrongly signed or where the short-term import price coefficient was larger than that for the long-term cost share.

Wage/price block dynamics. The dynamics of the price response to different cost shocks depends on the pattern of lags in the cost variables, the share of domestic and foreign costs in total cost and the error-correction coefficient. Table 6 takes Belgium as an example and shows the response of the private consumption deflator to different shocks holding a selection of other model variables constant. An increase in the level of all cost components by 1 per cent, holding other variables fixed, would increase the price deflator by 0.4 per cent after one year. Prices go up somewhat more than the initial shock in the third year and full homogeneity between cost and price levels is reached after the seventh year. The second panel in Table 6 shows an ex-ante shock to wages, with only prices, wages; capital cost and import prices endogenous. The wage increase would lead to a sharp acceleration in prices in the first three years after which price increases decelerate and finally stabilise after six years. The third panel simulates an import price shock, with wages, capital costs and prices endogenous. Domestic price deflators and wages regain half of the difference to foreign prices after about three years. Adjustment slows afterwards and full adjustment is reached after seven years. A one-period shock to the gap term, shown in the fourth panel, leads to an increase in prices and afterwards in wages. Both wages and prices stabilise after seven years somewhat above the baseline level.

\section{SIMULATION PROPERTIES}

A series of full-model shocks were simulated in order to highlight the interaction between the wage/price block and the other parts of the model. The simulations were carried out with the Spring 1990 version of INTERLINK, which includes not only new supply blocks for the smaller countries, but also new consumption functions and major changes to the government accounts. The 
results of the following shocks in single country mode are summarised in Tables 7 to 9 :

- a fiscal shock to government non-wage expenditure with fixed nominal interest and exchange rates;

- a monetary shock which lowers nominal interest rates with fixed real government expenditure and floating exchange rates;

- an exchange-rate shock with fixed nominal interest rates and fixed real government expenditure.

Eiscal shock. The fiscal shock increases total domestic demand by about the same amount as government spending in the short run (Table 7). But short-run effects on aggregate output and labour markets, which are the most important determinants for the ensuing wage/price dynamics, differ across countries: demand leakages via imports nearly offset the boost to domestic demand in Belgium, while the output multiplier is large in Australia, Finland and Spain. Wage and price reactions, therefore, also differ significantly across countries. In the following years, wage and price increases stimulate demand further through a fall in real interest rates, but also dampen demand because rising export prices erode competitiveness.

Under the assumption of a fixed nominal exchange rate the erosion of competitiveness is the major factor pushing demand back to baseline in the longer run. Wages and prices also react with some lag and fall back towards baseline values. As expected, given their generally greater openness, the reaction of wages and prices for the average of the smaller countries to the fiscal shock is smaller than that of the large countries (Table 10). Also the peak deviation of prices and wages from baseline occurs considerably sooner.

Monetary shock. A reduction in the short-term interest rate lowers the borrowing cost of consumers and producers, boosting private consumption, housing and business investment (Table 8). At the same time it affects prices more directly by inducing a fall in the exchange rate and lowering capital cost. The net effect is a small increase in wages and prices in the short run. In most countries, inflation accelerates due to an inflation/devaluation spiral and a considerable fall in real interest rates. Thus, growth rates of wages 
and prices are in general still higher than in the baseline by the fifth year. In comparison with the major seven countries, larger foreign demand leakages are a major reason for smaller output and price effects (Table 10).

Exchange-rate shock. A devaluation raises prices directly in the short run via increased import costs (Table 9). Wages respond with some lag. In addition, the short-run gain in competitiveness translates into an increase in net exports, which is large in some of the more open smaller countries. This, in turn, reduces unemployment and goods market slack and gives an additional boost to wage and price inflation. After about four years, wages and prices have risen by about 10 per cent above baseline (in response to a devaluation of 10 per cent) but then continue to increase further to reach a peak of about 12 per cent after six years before falling back (average for the smaller countries in Table 10 ).

This overshooting is due mainly to the fall in real interest rates, which boosts interest-sensitive demand components. But import prices also increase by more than implied by the devaluation as import price behaviour is affected by domestic price developments. In the longer run wage and price inflation turn around as the loss in competitiveness leads to slack in goods and labour markets. As shown in Table 10, the short-run response of wages and prices of the smaller countries is somewhat stronger than in the large countries, while peak deviations from the baseline are considerably larger.

\section{CONCLUDING REMARKS}

As the most important use of INTERLINK is the simulation of short to medium-run policy scenarios, the major aim of the work on wage and domestic price formation for the smaller OECD Member countries has been guided by the need to improve simulation properties of the model.

Work on wage equations follows closely the earlier work for the large countries. Testing of these equations has proceeded much further than for domestic demand deflator equations, which have only recently been implemented. Further work on smaller country wage equations is likely to take up issues 
which have recently been broached for the large countries: a more explicit modelling of the natural rate and of price expectations (Poret, 1990).

There are a number of areas where the new price blocks may be improved. First, sample periods are short for most countries and an effort has to be made to push samples backwards. Second, the way short-cuts have been taken, for instance with respect to the calculation of the government consumption deflator or the incorporation of indirect taxes, may be reconsidered. And third, a number of restrictions have been imposed, which could presumably be relaxed for a large number of countries.

Simulation results for the wage/price block and the full smaller country models, which now bring together earlier supply and demand side work, are encouraging. They are still preliminary, however, as further work is envisaged to improve the fiscal and monetary blocks and household accounts. 


\section{NOTES}

1. Major components of the research on wage and price stickiness comprise theories based on staggered contracts in labour markets, implicit contract models or the "menu cost" approach to price adjustment. Bruno (1989), Grandmont (1989) and Layard and Bean (1989) recently reviewed the development of these strands of research.

2. Because of data limitations the dependent variable is total business sector compensation per employee in the cases of Greece, Ireland and New Zealand.

3. A hysteresis specification, where the labour market pressure variable is represented by a moving average of the unemployment rate, had the same explanatory power as the logarithmic version in the case of Spain.

4. In all countries wages are indexed to present and past inflation in a more or less formal way. However, indexation is usually not 100 per cent, nor does it cover all the labour force. In addition, multi-year contracts do not allow for a quick feed-through of inflation into wage increases.

5. However, recent studies (Englander and Stone, 1989; Moghadam and Wren-Lewis, 1989; and Poret, 1990) found opposite results.

6. An extended Scandinavian model of inflation is estimated for Sweden in a recent OECD Economic Survey for Sweden (OECD, 1989).

7. The average natural rate $\left(\bar{U}^{*}\right)$ is close to the average unemployment rate (U) over the sample period for the linear case. As the equation passes through the mean values of the variables, rearrangement of the wage equation gives:

$\bar{w}=a_{0}+\bar{p}+a_{3} \bar{q}-a_{2} \bar{U}$ and

$\bar{U}=\left(a_{0}-(\bar{w}-\bar{p})+a_{3} \bar{q}\right) / a_{2}$.

If real wage growth equals productivity in the long run, the second equation is the same as the one used for calculating the natural rate in the linear case and $\bar{U}=\bar{U}^{*}$. In the logarithmic case, $U^{*}$ is equal to the geometric average of the actual unemployment rate and in the inverse case to the harmonic average. As both the geometric and harmonic averages are smaller than the arithmetic average, natural rates in the non-linear cases may appear low as compared to average actual unemployment rates.

8. Growth in government wage rates depend on private sector wage inflation in nearly all small country models. Estimated equations only exist for Denmark, the Netherlands and Sweden, where government wages are related to a distributed lag of private sector wage rates and an errorcorrection term in the levels of private and government sector wages. 
9. The private consumption deflator for Australia also includes a term for administered prices, with a weight of 0.27 . In simulations the administered component is linked to the overall private consumption deflator. In the case of the Netherlands, the private consumption deflator includes an additional component for quaternary services with a weight of 0.28 and for natural gas deliveries with a weight of 0.07 . The latter component also enters the government non-wage deflator with a weight of 0.06 . 


\section{BIBLIOGRAPHY}

Bruno, M. (1989), "Theoretical developments in the light of macroeconomic policy and empirical research". Scandinavian Journal of Economics 91(2), pp. $307-333$.

Coe, D.T. and F. Gagliardi (1985), "Nominal wage determination in ten OECD countries", QECD Economics and Statistics Department Working Papers, No. 19.

Coe, D.T. (1985), "Nominal wages, the NAIRU and wage flexibility", OECD Economic Studies, No. 5 (Autumn).

Englander, A.S. and G. Stone (1989), "Inflation expectations surveys as predictors of inflation and behaviour in financial and labour markets; Eederal Reserve Bank of New York Quarterly Review, (Autumn).

Grandmont, J.M. (1989), "Keynesian issues and economic theory", Scandinavian Journal of Economics 91(2), pp. 265-293.

Herd, R. (1987), "Import and export price equations for manufactures", OECD Economics and Statistics Department Working Papers, No. 43.

Holtham, G., T. Saavalainen, P. Saunders and H. Sutch (1985), "Commodity prices in INTERLINK", OECD Economics and Statistics Department Working Papers, No. 27 .

Layard, R. and C. Bean (1989), "Why does unemployment persist?", Scandinavian Journal of Economics 91(2), pp. 371-396.

Lucas, R.E. (1976), "Econometric policy evaluation: a critique", in: K. Brunner and A. Meltzer (eds.). The Phillips Curve and Labor Markets, Carnegie Rochester Conference Series, Vol. 1.

Moghadam, R. and S. Wren-Lewis (1989), "Are wages forward looking?", National Institute of Economic and Social Research, Discussion Papers, (September).

OECD (1989), OECD Economic Surveys, Sweden, Paris.

OECD (1987), OECD Economic Surveys, New Zealand, Paris.

Poret, P. (1990), "The "puzzle" of wage moderation in the 1980s", OECD, mimeo.

Richardson P. (1988), "The structure and simulation properties of OECD's Interlink model", OECD Economic Studies, No. 10 (Spring).

Richardson, P. (1987), "Recent developments in OECD's international macroeconomic model", OECD Economics and Statistics Department Working Papers, No. 46. 
Stiehler, U. (1987), "Price determination in the major seven country models in INTERLINK", OECD EConomics and Statistics Department Working Papers, No. 44.

Torres, R., P. Jarrett and W. Suyker (1989), "Modelling business sector supply for the smaller OECD countries", OECD Economics and Statistics Department Working Papers, No. 71.

Torres, R. and J.P. Martin (1990), "Measuring potential output in the seven major OECD countries", OECD Economic Studies, No. 14 (Spring). 
Table 1

On1t root tente

\begin{tabular}{|c|c|c|c|c|c|c|}
\hline & & & $\begin{array}{l}\text { Alternat } \\
\Phi_{3}\end{array}$ & $\begin{array}{l}\text { Ive } 3 \\
\cdot \Phi_{2}\end{array}$ & $\underset{\Phi_{1}}{\text { Alternativo }} 2$ & $\begin{array}{c}\text { Alternative } 1 \\
{ }^{\prime} \alpha{ }^{\prime}\end{array}$ \\
\hline Austral1a & (35) & $\begin{array}{l}\text { (1) } \\
\text { (2) }\end{array}$ & $\begin{array}{l}2.24 \\
2.48\end{array}$ & $\begin{array}{l}1.58 \\
2.25\end{array}$ & $\begin{array}{l}1.24 \\
2.24\end{array}$ & $\begin{array}{r}0.39 \\
-1.86\end{array}$ \\
\hline Austria & (41) & $\begin{array}{l}\text { (1) } \\
\text { (2) }\end{array}$ & $\begin{array}{l}1.61 \\
2.24\end{array}$ & $\begin{array}{l}1.10 \\
2.30\end{array}$ & $\begin{array}{l}1.10 \\
1.98\end{array}$ & $\begin{array}{r}0.23 \\
-1.72\end{array}$ \\
\hline Belgium & (34) & $\begin{array}{l}(1) \\
(2)\end{array}$ & $\begin{array}{l}6.55 \\
--\end{array}$ & $\begin{array}{c}4.36 \\
\ldots\end{array}$ & $\begin{array}{c}1.43 \\
--\end{array}$ & $\begin{array}{l}-0.15 \\
-1.59\end{array}$ \\
\hline Denmark & (34) & $\begin{array}{l}(1) \\
(2)\end{array}$ & $\begin{array}{l}3.64 \\
7.64 \star\end{array}$ & $\begin{array}{c}2.64 \\
--\end{array}$ & $\begin{array}{c}0.47 \\
--\end{array}$ & $\begin{array}{c}0.70 \\
--\end{array}$ \\
\hline Finland & (39) & $\begin{array}{l}(1) \\
(2)\end{array}$ & $\begin{array}{c}1.75 \\
11.68 *\end{array}$ & $\begin{array}{c}3.18 \\
--\end{array}$ & $\begin{array}{c}3.30 \\
-.\end{array}$ & $\begin{array}{c}-0.26 \\
--\end{array}$ \\
\hline Greece & $(40)$ & $\begin{array}{l}(1) \\
\text { (2) }\end{array}$ & $\begin{array}{l}3.52 \\
3.87\end{array}$ & $\begin{array}{l}2.35 \\
3.42\end{array}$ & $\begin{array}{l}1.69 \\
2.47\end{array}$ & $\begin{array}{r}-0.51 \\
0.39\end{array}$ \\
\hline Ireland & (35) & $\begin{array}{l}\text { (1) } \\
\text { (2) }\end{array}$ & $\begin{array}{l}7.11^{\star} \\
5.04\end{array}$ & $-\overline{1.04}$ & $1 . \overline{10}$ & -0.73 \\
\hline wetherlands & (33) & $\begin{array}{l}\text { (1) } \\
\text { (2) }\end{array}$ & $\begin{array}{l}2.10 \\
2.48\end{array}$ & $\begin{array}{l}1.93 \\
1.88\end{array}$ & $\begin{array}{l}1.08 \\
3.58\end{array}$ & $\begin{array}{c}1.12 \\
-2.19\end{array}$ \\
\hline Now zealand & (41) & $\begin{array}{l}\text { (1) } \\
\text { (2) }\end{array}$ & $\begin{array}{l}2.56 \\
1.72\end{array}$ & $\begin{array}{l}1.71 \\
1.15\end{array}$ & $\begin{array}{l}1.92 \\
1.74\end{array}$ & $\begin{array}{l}-0.36 \\
-1.05\end{array}$ \\
\hline Norway & $(40)$ & $\begin{array}{l}\text { (1) } \\
(2)\end{array}$ & $\begin{array}{l}2.87 \\
2.24\end{array}$ & $\begin{array}{l}2.17 \\
2.15\end{array}$ & $\begin{array}{l}0.56 \\
2.17\end{array}$ & $\begin{array}{r}0.70 \\
-1.79\end{array}$ \\
\hline spain & $(35)$ & $\begin{array}{l}\text { (1) } \\
\text { (2) }\end{array}$ & 3.41 & 2.44 & $2 . \overline{77}$ & $\begin{array}{r}1.32 \\
-1.52\end{array}$ \\
\hline sweden & (35) & $\begin{array}{l}\text { (1) } \\
\text { (2) }\end{array}$ & $\begin{array}{l}1.86 \\
2.36\end{array}$ & $\begin{array}{l}1.69 \\
1.78\end{array}$ & $\begin{array}{l}1.59 \\
1.12\end{array}$ & $\begin{array}{r}0.94 \\
-1.12\end{array}$ \\
\hline switzerland & $(40)$ & $\begin{array}{l}\text { (1) } \\
\text { (2) }\end{array}$ & $\begin{array}{c}3.42 \\
10.80^{\star}\end{array}$ & $\begin{array}{c}3.86 \\
--\end{array}$ & $\begin{array}{l}6.95 \star \\
--\end{array}$ & $\begin{array}{l}-- \\
--\end{array}$ \\
\hline
\end{tabular}

In brackete: number ( $T$ ) of observations (semi-annual data). An asterisk donotes that the non-stationarity hypothesis is refected; that 1s, the sories are etationary.

(1) Logarithm of the ratio of real consumption wages to current labour efficlency (business sector).

(2) Logarithm of the ratio of the private consumption deflator to total weighted costa. 
Note to Table 1

\section{Deacription of the test}

A variable, $X$, is sald to be stationary if the coefficiont $(\rho)$ of the one-period lagged $\chi$ io inferior to untty in an equation ouch as: $X_{t}=p+\rho X_{t-1}$, or equivalently if $\alpha=\rho-1$ lo atrictly inferior to 0 in $\Delta \chi_{t}=\mu+\alpha \chi_{t-1}$

More specifically, the test is the Augmented Dickey-Fuller test (using fourth-order correction). The testing strategy (Perron, Journal of Economic Dynamice and Control (12), 1988) goes from "general" to "opecific". One starts by testing the null hypothesis of a unit root with a drift and no time trend $\left(\Delta \chi_{t}-\mu+\alpha \chi_{t-1}+\epsilon_{t}\right)$ against Alternative 3, which 1s:

$$
\Delta x_{t}=\mu+\beta(t-T / 2)+\alpha \chi_{t-1}+\sum_{1=1}^{4} \gamma_{1} \Delta \chi_{t-1}+u_{t}
$$

The teat statistic $\left(\Phi_{3}\right)$ is therefore for the constraint that $\alpha=\beta=0$. If $\Phi_{3}$ exceeds the critical value, one rejects the null (1.e. "acccepts" that $\chi$ is tationary, perhaps with a time trend; the hypothesis that $\alpha=0$ and $\beta$ is non-zero is not tested) and the procedure ends. If not, one would "accept" that $\chi$ is a random walk, but this result could be due to the fact that the asoumption of a non-zero drift in the null is erroneous. To check that, one repeats the process, except the null has no drift $\left(\Delta X_{t}=\epsilon_{t}\right)$. The test statistic $\left(\Phi_{2}\right)$ 1s thus for the conetraint that $\mu=\alpha=\beta=0$. If $\Phi_{2}$ exceeds the critical value, this is tantamount to rejecting $\mu=0$ (given the previous test). Thus, the original null was fine, and the procedure ends by "accepting" non-stationartty on the basis of $\Phi_{3}$. If $\Phi_{2}$ does not exceed the critical value, the appropriate null does not include a drift. However, the procedure cannot ond by acceptance of driftless non-stationarity because $\Phi_{2}$ is not invariant with respect to the presence of a time trend in the alternative. Therefore, a more appropriate test may be agalnst Alternative 2, which 1s:

$$
\Delta \chi_{t}=\mu^{\star}+\alpha^{\star} \chi_{t-1}+\sum_{1=1}^{4} \gamma_{1}^{\star} \Delta \chi_{t-1}+u_{t}{ }^{\star}
$$

The test statistic $\left(\Phi_{1}\right)$ is thus for the constraint that $\mu^{\star}=\alpha^{\star}=0$ (but under a different null than $\Phi_{3}$ ). If $\Phi_{1}$ exceeds the critical value, one rejecto the null hypothesis of non-stationarity and the procedure ends, $\Phi_{1}$ being invariant to the presence of a non-zero mean in the alternative. If $\Phi_{1} 1 \mathrm{~s}$ below the critical value, one accepts the non sationarity after having checked, on the basis of 1ts $t$-statistics, that $\alpha$ is not significantly lese than zero in Alternative 1 (where $\mu=0$, as the series may have a zero mean in the alternative):

$$
\Delta \chi_{t}=\alpha^{\prime} \chi_{t-1}+\sum_{1=1}^{4} \gamma_{1}^{\prime} \Delta \chi_{t-1}+u_{t}^{\prime}
$$

The column $t \alpha^{\prime}$ gives the $t$-statistlcs associated wtth the coefflcient of $\chi_{t-1}$ $\left(\alpha^{\prime}\right)$ in Alternative 1 . $\Phi 3, \Phi 2, \Phi 1$ are the $F-a t a t i s t i c s$ easociated with the foint test of the null hypotheses, respectively $(\mu, \beta, \alpha)=(\mu, 0,0) ;(\mu, \beta$, a) $=(0,0,0) ;\left(\mu^{*}, \alpha^{*}\right)=(0,0)$. Critical values do not follow the uaual $t-$ and F-distributtons. For 50 observations, the critical value for the $t$-etatistice at the 5 per cent level for Alternative 1 is -1.95 (Fuller (1976), Introduction to statiatical rime series. $p .373)$. The critical values for $\Phi_{3}$, $\bar{\Phi}_{2}$ and $\bar{\Phi}_{1}$ are $6.73,5.13,4.86$ (Dickey and Fuller (1981), Econometrica 4, p. 1063).

The above testing strategy ensures that the null hypothesis of non-stationarity with a non-zero drift is checked firat. $\Phi$ teats are not reported when $\alpha$ is positive (that $1 s, \rho>1$ ) since, although $\alpha$ may be algnificantly different from zero, the series is obviously. non-atationary (1t follows an explosive process). 
Table 2

Aggrogete nog ogatione (a)

\begin{tabular}{|c|c|c|c|c|c|c|c|c|c|c|}
\hline & \multirow{2}{*}{ Constant } & \multicolumn{3}{|c|}{ Unemployment rate (U) } & \multirow{2}{*}{$\begin{array}{c}\text { Infletion } \\
\text { (b) }\end{array}$} & \multirow{2}{*}{$\begin{array}{l}\text { Productivity } \\
\text { growth (c) }\end{array}$} & \multirow{2}{*}{$\begin{array}{l}\text { Output prioe } \\
\text { effect (d) }\end{array}$} & \multirow{2}{*}{$\operatorname{sez}$} & \multirow{2}{*}{ DW } & \multirow{2}{*}{$A d j R^{2}$} \\
\hline & & $v$ & $\ln v$ & $1 / 0$ & & & & & & \\
\hline $\begin{array}{l}\text { Auptralia } \\
1970 I I-1985 I I\end{array}$ & $\begin{array}{r}2.11 \\
(0.0)\end{array}$ & $\begin{array}{r}-0.39 \\
(2.6)\end{array}$ & & & $\begin{array}{r}1.14 \\
(2.8)\end{array}$ & & & 1.94 & 1.9 & 0.66 \\
\hline $\begin{array}{l}\text { Austrid } \\
1969 I-86 I I\end{array}$ & $\begin{array}{c}2.10 \\
(5.4)\end{array}$ & & $\begin{array}{r}-1.73 \\
(3.1)\end{array}$ & & $\begin{array}{l}1 \\
(1)\end{array}$ & & $\begin{array}{c}-1.03 \\
(1.8)\end{array}$ & 1.45 & 2.6 & 0.50 \\
\hline $\begin{array}{l}\text { Belgtum } \\
1971-88\end{array}$ & $\begin{array}{r}5.13 \\
(4.3)\end{array}$ & $\begin{array}{l}-0.54 \\
(5.6)\end{array}$ & & & $\begin{array}{l}1 \\
\text { (1) }\end{array}$ & $\begin{array}{c}0.76 \\
(4.0)\end{array}$ & $\begin{array}{c}-0.46 \\
(2.4)\end{array}$ & 1.41 & 2.5 & 0.04 \\
\hline $\begin{array}{l}\text { Dentwark } \\
19661 I-87 I I\end{array}$ & $\begin{array}{r}1.96 \\
(3.5)\end{array}$ & & $\begin{array}{r}-1.11 \\
(5.6)\end{array}$ & & $\begin{array}{l}1 \\
\text { (i) }\end{array}$ & $\begin{array}{r}0.46 \\
(2.1)\end{array}$ & & 0.66 & 2.0 & 0.80 \\
\hline $\begin{array}{l}\text { Finland } \\
1967 I I-86 I I\end{array}$ & $\begin{array}{r}3.20 \\
(2.1)\end{array}$ & & $\begin{array}{l}-2.06 \\
(2.9)\end{array}$ & & $\stackrel{1}{1}$ & $\begin{array}{r}0.83 \\
(2.4)\end{array}$ & & 1.61 & 2.2 & 0.48 \\
\hline $\begin{array}{l}\text { Greece } \\
1963 I-86 I I\end{array}$ & $\begin{array}{r}2.10 \\
(2.3)\end{array}$ & $\begin{array}{l}-0.41 \\
(2.5)\end{array}$ & & & $\begin{array}{l}i \\
(1)\end{array}$ & $\begin{array}{r}1.01 \\
(6.1)\end{array}$ & $\begin{array}{l}-0.50 \\
(1)\end{array}$ & 2.17 & 1.6 & 0.47 \\
\hline $\begin{array}{l}\text { Ireland } \\
1970 I-86 I I\end{array}$ & $\begin{array}{r}6.40 \\
(2.7)\end{array}$ & & $\begin{array}{c}-2.16 \\
(2.0)\end{array}$ & & $\begin{array}{c}1 \\
(1)\end{array}$ & & $\begin{array}{r}-0.73 \\
(3.3)\end{array}$ & 2.17 & 1.4 & 0.49 \\
\hline $\begin{array}{l}\text { Netherlande } \\
\text { 1971I-asII }\end{array}$ & $\begin{array}{r}4.13 \\
(7.4)\end{array}$ & & $\begin{array}{l}-1.74 \\
(6.0)\end{array}$ & & $\begin{array}{c}1 \\
(i)\end{array}$ & & & 0.85 & 2.2 & 0.75 \\
\hline $\begin{array}{l}\text { New Zealand } \\
1967 I-86 I I\end{array}$ & $\begin{array}{r}1.10 \\
(1.7)\end{array}$ & $\begin{array}{r}-0.65 \\
(2.4)\end{array}$ & & $:$ & $\begin{array}{c}1 \\
\text { (i) }\end{array}$ & $\begin{array}{r}0.78 \\
(1.8)\end{array}$ & $\begin{array}{c}-0.80 \\
(1.8)\end{array}$ & 2.72 & 1.9 & 0.55 \\
\hline $\begin{array}{l}\text { Norway } \\
1971 I-B 6 I I\end{array}$ & $\begin{array}{r}-1.70 \\
(1.4)\end{array}$ & & & $\begin{array}{r}2.73 \\
(1.3)\end{array}$ & $\begin{array}{c}1 \\
(1)\end{array}$ & $\begin{array}{r}0.81 \\
(3.0)\end{array}$ & $\begin{array}{r}-0.60 \\
(1.7)\end{array}$ & 1.61 & 2.2 & 0.45 \\
\hline $\begin{array}{l}\text { Spain } \\
1964 I-84 I I\end{array}$ & $\begin{array}{r}2.94 \\
(1.8)\end{array}$ & & $\begin{array}{l}-1.74 \\
(0.5)\end{array}$ & & $\begin{array}{c}1.03 \\
(6.4)\end{array}$ & $\begin{array}{r}0.77 \\
(1.8)\end{array}$ & & 1.78 & 2.3 & 0.58 \\
\hline $\begin{array}{l}\text { Sweden } \\
\text { 1972II-B4II }\end{array}$ & $\begin{array}{l}-3.81 \\
(2.6)\end{array}$ & & & $\begin{array}{c}7.78 \\
(2.5)\end{array}$ & $\begin{array}{c}1 \\
(1)\end{array}$ & - & $\begin{array}{r}-0.62 \\
(3.3)\end{array}$ & 1.62 & 1.3 & 0.76 \\
\hline $\begin{array}{l}\text { Switrerland } \\
1962 \mathrm{II}-86 \mathrm{II}\end{array}$ & $\begin{array}{l}38.10 \\
(3.3)\end{array}$ & $\begin{array}{l}0.39(0) \\
(3.3)\end{array}$ & & & $\begin{array}{c}1 \\
(1)\end{array}$ & $\begin{array}{r}0.56 \\
(4.4)\end{array}$ & $\begin{array}{c}-0.91 \\
(5.4)\end{array}$ & 0.86 & 2.6 & 0.76 \\
\hline
\end{tabular}

a) The dependent variable is the growth of the wage rete excopt for Greece, Ireland and Now zealand. All -quatione are entimated by two-stege leat equares on eseoselly-adjueted eemi-annual date except for Belgiu where annuel dete are ueed. T-otatietice eppear in parenthesen below the coefficient estimater.

b) Inflation ie defined as a moving average of current and paet grovth of the peraonal coneumption deflator for all countries excopt Belgium for whioh no lagged effect of inflation wav found. $A$ two-period weighted moving average in uned for Norway (weighte of $0.39,0.61$ ) and Ireland $(0.62,0.38$ ). For the other countries, the inflation term is a moving average of either two periode (Australia, the Netherlande, Switzerland, Greece), three periode (Auetria, Finland) or four periode (Spain).

c) Productivity growth is specified as a two-period moving average for Norway; for Denmerk, Finland and Spein, it is a three-period moving average; for Switzerland it is unlagged. Businese eector productivity i. used.

d) Difference between the growth of the private consumption deflator end the growth of the bueinene ector output deflator. The export deflator for goods and eervices is used for sweden, inetead of the businese eector output deflator.

e) The activity variable for Switzerland is a measure of the employment rate defined as total amployment divided by a lagged two-period moving everege of the labour force, multiplied by 100 . 
Note to Table 2

Country-specific dumny variables in the wage equations

\begin{tabular}{|c|c|c|c|}
\hline Country & Values & $\begin{array}{l}\text { Parameter } \\
\text { estimate }\end{array}$ & t-ratio \\
\hline \multirow[t]{3}{*}{ Sweden } & $\begin{array}{l}-1 \text { and } 1 \text { in the first and } \\
\text { second semesters of } 1973,1974 \text { and } 1979\end{array}$ & 3.34 & $(4.99)$ \\
\hline & $\begin{array}{l}-1 \text { and } 1 \text { in the first and second } \\
\text { semesters of } 1977\end{array}$ & -5.92 & $(5.14)$ \\
\hline & $\begin{array}{l}-1 \text { and } 1 \text { in the first and second } \\
\text { semesters of } 1973,1980,1981\end{array}$ & -3.14 & $(4.70)$ \\
\hline New Zealand & 1 in $1986 I$ & 12.27 & $(3.1)$ \\
\hline Australia & 1 from 1974 I to 1974 II & 5.81 & $(2.24)$ \\
\hline Netherlands & 1 from $1980 \mathrm{I}$ to $1981 \mathrm{I}$ & -3.48 & $(6.70)$ \\
\hline Austria & 1 in $1971 \mathrm{I}$ & 6.5 & $(4.2)$ \\
\hline
\end{tabular}


Table 3

Natural rate of unemployment estimates

\begin{tabular}{lrrr|rrr}
\hline & \multicolumn{3}{c}{ Unemployment rate } & Natural rate of unemployment \\
\cline { 2 - 6 } & $1966 / 87$ & $1980 / 87$ & 1988 & $1966 / 73$ & $1974 / 79$ & $1980 / 87$ \\
\cline { 2 - 6 } & 4.9 & 7.7 & 7.1 & 2.8 & 3.2 & 5.1 \\
Australia & 2.0 & 3.1 & 3.6 & 0.7 & 1.2 & 2.8 \\
Austria & 6.5 & 11.4 & 10.3 & 5.9 & 6.5 & 6.5 \\
Belgium & 5.3 & 8.9 & 8.6 & 4.3 & 6.0 & 6.9 \\
Denmark & 37 & 51 & 4.6 & 4.0 & 4.0 & 4.1 \\
Finland & 4.3 & 6.4 & 7.7 & 5.2 & 5.1 & 5.1 \\
Greece & 9.1 & 13.8 & 167 & 7.3 & 6.5 & 5.9 \\
Ireland & 4.3 & 8.7 & 8.3 & 2.5 & 4.3 & 6.0 \\
Netherlands & 1.8 & 3.9 & 6.0 & 1.6 & 1.5 & 1.6 \\
New Zealand & 1.9 & 2.4 & 3.2 & 1.2 & 1.5 & 1.5 \\
Norway & 8.4 & 17.9 & 19.5 & 6.7 & 6.7 & 7.4 \\
Spain & 1.9 & 2.3 & 1.6 & 2.6 & 2.6 & 2.8 \\
Sweden & 0.3 & 0.6 & 0.7 & 0.5 & 1.3 & 0.8 \\
Switzerland & & & & & & \\
\hline
\end{tabular}


Table 4

Indirect tax rate assumptions

(Value is one where indirect tax rate applies; zero otherwise)

\begin{tabular}{lccccc}
\hline & PCP & PCGN & PIH & PIB & PIG \\
\cline { 2 - 6 } & & & & & \\
Australia & 1 & 0 & 0 & 0 & 0 \\
Austria & 1 & 1 & 1 & 0 & 1 \\
Belgium & 1 & 1 & 1 & 0 & 1 \\
Denmark & 1 & 1 & 1 & 0 & 1 \\
Finland & 1 & 0 & 0 & 0 & 0 \\
Greece & 1 & 0 & 0 & 0 & 0 \\
Ireland & 1 & 0 & 0 & 0 & 0 \\
Netherlands & 1 & 0 & 1 & 1 & 1 \\
New Zealand & 1 & 1 & 1 & 1 & 1 \\
Norway & 1 & 0 & 0 & 0 & 0 \\
Spain & 1 & 0 & 0 & 0 & 0 \\
Sweden & 1 & 1 & 1 & 0 & 0 \\
Switzerland & 1 & 1 & 1 & 1 & 1 \\
& & & & & \\
\hline
\end{tabular}

PCP Private consumption deflator

PCGNW Government non-wage consumption deflator

PIH Residential construction deflator

PIB Business investment deflator

PIG Government investment deflator 
Table 5

Equetions for donetic damind derletore (a)

\begin{tabular}{|c|c|c|c|c|c|c|c|c|c|}
\hline & Short-term & Error- & Iong-texw & & & & & & \\
\hline Conetant & $\begin{array}{c}\text { import prife } \\
\text { offect }\end{array}$ & $\begin{array}{c}\text { correction } \\
\text { term }\end{array}$ & $\begin{array}{c}\text { Import price } \\
\text { effect }\end{array}$ & $\begin{array}{l}\text { Gap term } \\
\text { (b) }\end{array}$ & Ruste & $\mathrm{R}^{2}$ & DM & Dh & RHO1 \\
\hline
\end{tabular}

Auptralia (Sample - 1973I-1986II; lag - 1 for Import and (for domestia cost; labour cost share - 0.62)

\begin{tabular}{|c|c|c|c|c|c|c|c|c|c|c|}
\hline $\begin{array}{l}\text { Private conoumption } \\
\text { deflator (o) } \\
:\end{array}$ & $\begin{array}{r}0.52 \\
(1.2)\end{array}$ & $\begin{array}{r}0.11 \\
(2.3)\end{array}$ & $\begin{array}{r}0.10 \\
(1.4)\end{array}$ & $\begin{array}{l}0.15 \\
(I)\end{array}$ & $\begin{array}{l}20.17 \\
(3.7)\end{array}$ & 1.07 & 0.67 & 1.82 & : & . \\
\hline $\begin{array}{l}\text { Government non-wage } \\
\text { conemaption deflator }\end{array}$ & $\begin{array}{r}1.72 \\
(2.5)\end{array}$ & $\begin{array}{r}0.07 \\
(0.5)\end{array}$ & $\begin{array}{r}0.62 \\
(10.2)\end{array}$ & $\begin{array}{l}0.10 \\
\text { (I) }\end{array}$ & $\begin{array}{l}00.17 \\
(3.7)\end{array}$ & 3.19 & 0.75 & 1.49 & & \\
\hline $\begin{array}{l}\text { Renldential con- } \\
\text { etruction deflator }\end{array}$ & $\begin{array}{r}0.96 \\
(1.7)\end{array}$ & $\begin{array}{r}0.11 \\
(1.1)\end{array}$ & $\begin{array}{r}0.16 \\
(1.0)\end{array}$ & 0.15 & $\begin{array}{l}20.17 \\
(3.7)\end{array}$ & 1.86 & 0.51 & 1.50 & 2.56 & $\begin{array}{r}0.34 \\
(2.0)\end{array}$ \\
\hline $\begin{array}{l}\text { Buelnene inveotment } \\
\text { defletor }\end{array}$ & $\begin{array}{r}2.04 \\
(5.5)\end{array}$ & $\begin{array}{r}0.29 \\
(5.3)\end{array}$ & $\begin{array}{r}0.40 \\
(5.9)\end{array}$ & $\begin{array}{l}0.45 \\
\text { (I) }\end{array}$ & $\begin{array}{l}20.17 \\
(3.7)\end{array}$ & 1.26 & 0.80 & 1.39 & & \\
\hline $\begin{array}{l}\text { Government investment } \\
\text { deflator }\end{array}$ & $\begin{array}{l}0.30 \\
(0.8)\end{array}$ & $\begin{array}{r}0.28 \\
(3.9)\end{array}$ & $\begin{array}{r}0.13 \\
(2.1)\end{array}$ & $\begin{array}{l}0.30 \\
\text { (I) }\end{array}$ & $\begin{array}{l}00.17 \\
(3.7)\end{array}$ & 1.65 & 0.72 & 1.76 & & \\
\hline
\end{tabular}

Auntria (Sample - 1971II-1986II; lag - 1 for import and 6 for domentic cost; labour cost ahare - 0.56)

\begin{tabular}{|c|c|c|c|c|c|c|c|c|c|c|}
\hline $\begin{array}{l}\text { Private coneumption } \\
\text { deflator }\end{array}$ & $\begin{array}{r}0.85 \\
(0.4)\end{array}$ & $\begin{array}{l}0.14 \\
(4.2)\end{array}$ & $\begin{array}{r}0.57 \\
(7.8)\end{array}$ & $\begin{array}{l}0.25 \\
(I)\end{array}$ & $\begin{array}{l}80.03 \\
(1.3)\end{array}$ & 0.82 & 0.64 & 2.39 & -1.15 & $\begin{array}{r}0.92 \\
(21.7)\end{array}$ \\
\hline $\begin{array}{l}\text { Covernment non-wage } \\
\text { coneumption deflator }\end{array}$ & $\begin{array}{r}0.75 \\
(1.1)\end{array}$ & $\begin{array}{r}0.09 \\
(0.6)\end{array}$ & $\begin{array}{r}0.24 \\
(4.4)\end{array}$ & $\begin{array}{l}0,20 \\
(I)\end{array}$ & $\begin{array}{l}20.03 \\
(1.3)\end{array}$ & 2.59 & 0.86 & 2.77 & 0.55 & $\begin{array}{r}0.30 \\
(3.3)\end{array}$ \\
\hline $\begin{array}{l}\text { Revidential con- } \\
\text { etruction doflator }\end{array}$ & $\begin{array}{l}-0.43 \\
(0.8)\end{array}$ & $\begin{array}{r}0.16 \\
(4.2)\end{array}$ & $\begin{array}{r}0.21 \\
(4.8)\end{array}$ & $\begin{array}{l}0.20 \\
\text { (I) }\end{array}$ & $\begin{array}{l}80.03 \\
(1.3)\end{array}$ & 1.66 & 0.61 & 1.91 & 0.12 & $\begin{array}{r}0.36 \\
(6.2)\end{array}$ \\
\hline $\begin{array}{l}\text { Businese invertment } \\
\text { deflator }\end{array}$ & $\begin{array}{l}-0.06 \\
(0.3)\end{array}$ & $\begin{array}{l}0.25 \\
\text { (I) }\end{array}$ & $\begin{array}{r}0.19 \\
(2.3)\end{array}$ & 0.45 & $\begin{array}{l}80.03 \\
(1.3)\end{array}$ & 1.10 & 0.54 & 2.45 & & \\
\hline $\begin{array}{l}\text { Government inveatment } \\
\text { deflator }\end{array}$ & $\begin{array}{l}-0.16 \\
(0.4)\end{array}$ & $\begin{array}{l}0.15 \\
\text { (I) }\end{array}$ & $\begin{array}{r}0.12 \\
(4.4)\end{array}$ & $\begin{array}{l}0.25 \\
\text { (I) }\end{array}$ & $\begin{array}{l}20.03 \\
(1.3)\end{array}$ & 1.52 & 0.13 & 1.72 & & \\
\hline
\end{tabular}

Belqiue (Sample - 1974I-1986II; lag - 2 for import and 6 for domestic cost; labour cost ohare - 0.69)

\begin{tabular}{|c|c|c|c|c|c|c|c|c|c|c|}
\hline $\begin{array}{l}\text { Private consumption } \\
\text { deflator }\end{array}$ & $\begin{array}{r}0.82 \\
(3.2)\end{array}$ & $\begin{array}{r}0.27 \\
(8.1)\end{array}$ & $\begin{array}{r}0.11 \\
(5.4)\end{array}$ & $\begin{array}{l}0.36 \\
(I)\end{array}$ & $\begin{array}{r}0.10 \\
(2.5)\end{array}$ & 0.78 & 0.82 & 1.30 & & \\
\hline $\begin{array}{l}\text { Government non-wage } \\
\text { connumption deflator }\end{array}$ & $\begin{array}{r}1.11 \\
(2.3)\end{array}$ & $\begin{array}{r}0.15 \\
(1.8)\end{array}$ & $\begin{array}{r}0.09 \\
(1.6)\end{array}$ & $\begin{array}{l}0.36 \\
\text { (I) }\end{array}$ & $\begin{array}{l}0.0 \\
\text { (I) }\end{array}$ & 2.36 & 0.46 & 1.47 & & \\
\hline $\begin{array}{l}\text { Realdential con- } \\
\text { otruction deflator }\end{array}$ & $\begin{array}{l}-0.22 \\
(0.3)\end{array}$ & $\begin{array}{l}0.28 \\
(I)\end{array}$ & $\begin{array}{l}0.0 \\
(I)\end{array}$ & $\begin{array}{l}0.28 \\
(I)^{2}\end{array}$ & $\begin{array}{l}0.0 \\
(I)\end{array}$ & 1.24 & 0.78 & 1.65 & 0.67 & $\begin{array}{r}0.70 \\
(7.4)\end{array}$ \\
\hline $\begin{array}{l}\text { Bueinese invertment } \\
\text { deflator }\end{array}$ & $\begin{array}{r}0.25 \\
(0.3)\end{array}$ & $\begin{array}{r}0.22 \\
(3.5)\end{array}$ & $\begin{array}{r}0.06 \\
(1.7)\end{array}$ & $\begin{array}{l}0.68 \\
(I)\end{array}$ & $\begin{array}{r}0.09 \\
(0.8)\end{array}$ & 1.00 & 0.70 & 1.76 & -0.04 & $\begin{array}{l}0.44 \\
(3.5)\end{array}$ \\
\hline $\begin{array}{l}\text { Government inveatment } \\
\text { deflator }\end{array}$ & $\begin{array}{l}-0.48 \\
(2.1)\end{array}$ & $\begin{array}{l}0.28 \\
(I)\end{array}$ & 0.0 & $\begin{array}{l}0.28 \\
\text { (I) }\end{array}$ & $\begin{array}{l}0.0 \\
\text { (I) }\end{array}$ & 0.82 & 0.83 & 1.14 & 2.43 & $\begin{array}{l}0.29 \\
(2.9)\end{array}$ \\
\hline
\end{tabular}

Denmark (Sample - 1974I-1986II; lag - 1 for import and 3 for domentic cont; laboux cost share - 0.66 )

\begin{tabular}{|c|c|c|c|c|c|c|c|c|c|c|}
\hline $\begin{array}{l}\text { Private convurption } \\
\text { deflator }\end{array}$ & $\begin{array}{r}0.24 \\
(0.8)\end{array}$ & $\begin{array}{r}0.18 \\
(3.9)\end{array}$ & $\begin{array}{r}0.34 \\
(3.5)\end{array}$ & $\begin{array}{l}0,24 \\
(I)\end{array}$ & $\begin{array}{l}00.06 \\
\text { (I) }\end{array}$ & 1.14 & 0.71 & 1.93 & & \\
\hline $\begin{array}{l}\text { Covernment non-wage } \\
\text { connumption deflator }\end{array}$ & $\begin{array}{r}1.26 \\
(2.2)\end{array}$ & $\begin{array}{r}0.22 \\
(2.0)\end{array}$ & $\begin{array}{l}0.56 \\
(3.3)\end{array}$ & $\begin{array}{l}0.27 \\
\text { (I) }\end{array}$ & $\begin{array}{l}80.06 \\
\text { (I) }\end{array}$ & 2.24 & 0.65 & 1.35 & & \\
\hline $\begin{array}{l}\text { Renidential con- } \\
\text { etruction defletor }\end{array}$ & $\begin{array}{r}1.06 \\
(1.0)\end{array}$ & $\begin{array}{l}0.24 \\
\text { (I) }\end{array}$ & $\begin{array}{r}0.45 \\
(1.1)\end{array}$ & $\begin{array}{l}0.19 \\
\text { (I) }\end{array}$ & $\begin{array}{l}00.06 \\
\text { (I) }\end{array}$ & 0.83 & 0.91 & 1.43 & & $\begin{array}{r}0.73 \\
(2.5)\end{array}$ \\
\hline $\begin{array}{l}\text { Government inventment } \\
\text { deflator }\end{array}$ & $\begin{array}{r}0.19 \\
(0.6)\end{array}$ & $\begin{array}{r}0.25 \\
(5.4)\end{array}$ & $\begin{array}{r}0.25 \\
(1.1)\end{array}$ & $\begin{array}{l}0.20 \\
(I)\end{array}$ & $\begin{array}{l}80.06 \\
\text { (I) }\end{array}$ & 0.92 & 0.85 & 1.60 & : & $\begin{array}{r}0.11 \\
(1.5)\end{array}$ \\
\hline
\end{tabular}


rable 5 (continued)

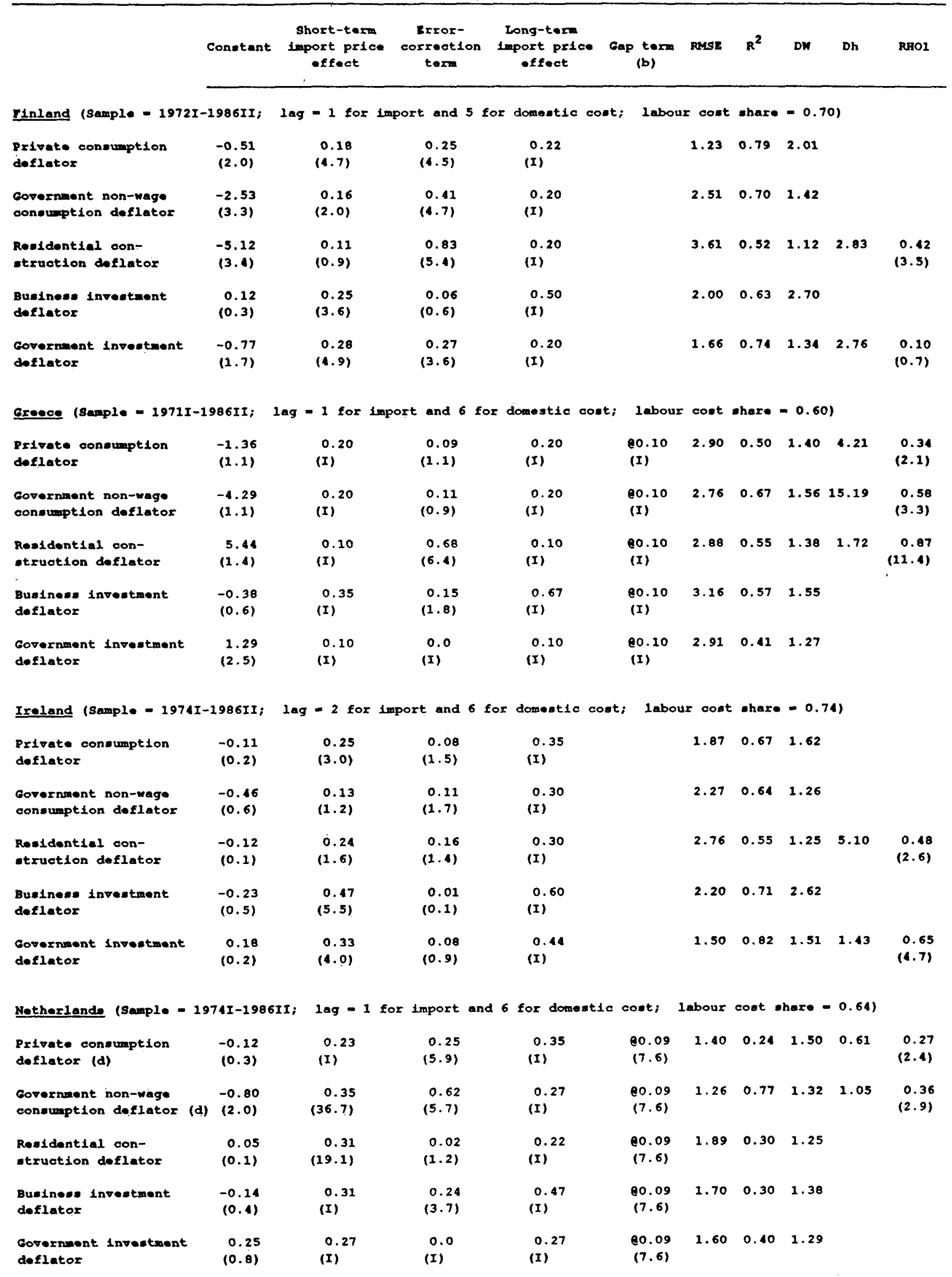


rable 5 (continued)

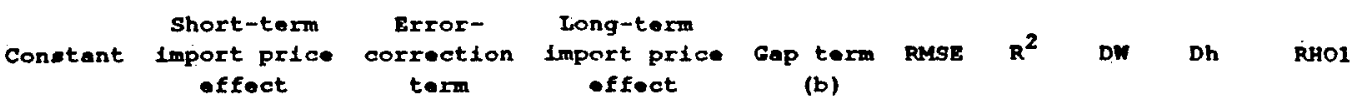

Nen zealand (Semple - 1972I-1986II; lag = 2 for import and 6 for domentic cont; laboux cont ahare - 0.52)

\begin{tabular}{|c|c|c|c|c|c|c|c|c|c|}
\hline $\begin{array}{l}\text { Private coneumption } \\
\text { deflator }\end{array}$ & $\begin{array}{r}0.73 \\
(1.4)\end{array}$ & $\begin{array}{r}0.22 \\
(3.1)\end{array}$ & $\begin{array}{r}0.14 \\
(2.1)\end{array}$ & $\begin{array}{l}0.32 \\
(I)\end{array}$ & 2.10 & 0.37 & 1.44 & & \\
\hline $\begin{array}{l}\text { Government non-wage } \\
\text { connumption deflator }\end{array}$ & $\begin{array}{l}-1.26 \\
(1.6)\end{array}$ & $\begin{array}{r}0.34 \\
(2.7)\end{array}$ & $\begin{array}{r}0.10 \\
(1.8)\end{array}$ & $\begin{array}{l}0.32 \\
(I)^{-32}\end{array}$ & 3.73 & 0.28 & 1.57 & & \\
\hline $\begin{array}{l}\text { Reaidential con- } \\
\text { etruction deflator }\end{array}$ & $\begin{array}{r}1.01 \\
(1.4)\end{array}$ & $\begin{array}{r}0.21 \\
(2.0)\end{array}$ & $\begin{array}{l}0.0 \\
\text { (I) }\end{array}$ & 0.24 & 2.57 & 0.35 & 1.49 & 1.90 & $\begin{array}{r}0.36 \\
(2.5)\end{array}$ \\
\hline $\begin{array}{l}\text { Business inventment } \\
\text { deflator }\end{array}$ & $\begin{array}{l}-1.56 \\
(1.6)\end{array}$ & $\begin{array}{r}0.42 \\
(3.2)\end{array}$ & $\begin{array}{r}0.53 \\
(2.7)\end{array}$ & 0.55 & 2.89 & 0.56 & 1.28 & & $\begin{array}{r}0.36 \\
(1.8)\end{array}$ \\
\hline $\begin{array}{l}\text { Government investment } \\
\text { deflator }\end{array}$ & $\begin{array}{l}-1.80 \\
(1.0)\end{array}$ & $\begin{array}{r}0.41 \\
(3.3)\end{array}$ & $\begin{array}{r}0.57 \\
(2.9)\end{array}$ & $\begin{array}{l}0.55 \\
(I)\end{array}$ & 2.67 & 0.60 & 1.34 & & $\begin{array}{r}0.41 \\
(2.1)\end{array}$ \\
\hline
\end{tabular}

Norwey (Sample - 1971I-1986II; lag - 2 for import and 4 for domestic cout; labour cost share - 0.60)

\begin{tabular}{|c|c|c|c|c|c|c|c|c|c|c|c|}
\hline $\begin{array}{l}\text { Private coneumption } \\
\text { deflator }\end{array}$ & $\begin{array}{r}0.39 \\
(1.2)\end{array}$ & $\begin{array}{r}0.25 \\
(3.2)\end{array}$ & $\begin{array}{r}0.25 \\
(2.5)\end{array}$ & $\begin{array}{l}0.30 \\
\text { (I) }\end{array}$ & & $\begin{array}{l}(0.08 \\
(1.8)\end{array}$ & 1.62 & 0.31 & 1.78 & & \\
\hline $\begin{array}{l}\text { Government non-wage } \\
\text { coneumption deflator }\end{array}$ & $\begin{array}{r}0.58 \\
(0.3)\end{array}$ & $\begin{array}{l}0.30 \\
\text { (I) }\end{array}$ & $\begin{array}{r}0.13 \\
(1.2)\end{array}$ & $\begin{array}{l}0.43 \\
\text { (I) }\end{array}$ & & $\begin{array}{l}80.08 \\
(1.8)\end{array}$ & 3.36 & 0.61 & 1.58 & & $\begin{array}{r}0.43 \\
(2.0)\end{array}$ \\
\hline $\begin{array}{l}\text { Residontial con- } \\
\text { etruction deflator }\end{array}$ & $\begin{array}{l}0.30 \\
(0.7)\end{array}$ & $\begin{array}{l}0.20 \\
\text { (I) }\end{array}$ & $\begin{array}{r}0.09 \\
(1.4)\end{array}$ & $\begin{array}{l}0.22 \\
\text { (I) }\end{array}$ & & $\begin{array}{l}80.08 \\
(1.8)\end{array}$ & 1.55 & 0.42 & 1.27 & & \\
\hline $\begin{array}{l}\text { Businese investment } \\
\text { deflator }\end{array}$ & $\begin{array}{r}0.20 \\
(0.4)\end{array}$ & $\begin{array}{l}0.30 \\
\text { (I) }\end{array}$ & $\begin{array}{r}0.30 \\
(3.4)\end{array}$ & $\begin{array}{l}0.55 \\
\text { (I) }\end{array}$ & & $\begin{array}{l}80.08 \\
(1.8)\end{array}$ & 2.56 & 0.70 & 1.94 & & \\
\hline $\begin{array}{l}\text { Government lnvestment } \\
\text { deflator }\end{array}$ & $\begin{array}{l}-0.27 \\
(0.4)\end{array}$ & $\begin{array}{l}0.20 \\
\text { (I) }\end{array}$ & $\begin{array}{r}0.03 \\
(0.8)\end{array}$ & $\begin{array}{l}0.22 \\
\text { (I) }\end{array}$ & & $\begin{array}{l}00.08 \\
(1.8)\end{array}$ & 1.46 & 0.38 & 1.31 & 5.21 & $\begin{array}{r}0.11 \\
(0.7)\end{array}$ \\
\hline Spain (Sample = 19741 & 86II; & lag $=1$ for & 1mport and 5 & for dometic & cost; & labour & $\cos t$ & hare - & $0.66)$ & & \\
\hline $\begin{array}{l}\text { Private coneumption } \\
\text { deflator }\end{array}$ & $\begin{array}{l}-0.87 \\
(1.4)\end{array}$ & $\begin{array}{r}0.12 \\
(2.3)\end{array}$ & $\begin{array}{r}0.27 \\
(3.2)\end{array}$ & $\begin{array}{l}0.33 \\
\text { (I) }\end{array}$ & & $\begin{array}{l}00.06 \\
(2.3)\end{array}$ & 2.47 & 0.50 & 2.36 & & \\
\hline $\begin{array}{l}\text { Government non-rage } \\
\text { coneumption deflator }\end{array}$ & $\begin{array}{l}-1.84 \\
(2.5)\end{array}$ & $\begin{array}{r}0.17 \\
(1.9)\end{array}$ & $\begin{array}{r}0.47 \\
(4.9)\end{array}$ & $\begin{array}{l}0.36 \\
\text { (I) }\end{array}$ & ' & $\begin{array}{l}20.06 \\
(2.3)\end{array}$ & 3.59 & 0.42 & 1.26 & & \\
\hline $\begin{array}{l}\text { Reaidential con- } \\
\text { etruction deflator }\end{array}$ & $\begin{array}{r}-1.33 \\
(2.3)\end{array}$ & $\begin{array}{r}0.07 \\
(2.6)\end{array}$ & $\begin{array}{r}0.20 \\
(6.0)\end{array}$ & $\begin{array}{l}0.12 \\
(I)\end{array}$ & & $\begin{array}{l}20.06 \\
(2.3)\end{array}$ & 1.52 & 0.84 & 0.99 & 2.74 & $\begin{array}{r}0.25 \\
(3.5)\end{array}$ \\
\hline $\begin{array}{l}\text { Bueinese investment } \\
\text { defletor }\end{array}$ & $\begin{array}{l}-0.31 \\
(0.8)\end{array}$ & $\begin{array}{r}0.12 \\
(2.9)\end{array}$ & $\begin{array}{l}0.15 \\
(7.8)\end{array}$ & $\begin{array}{l}0.47 \\
\text { (I) }\end{array}$ & & $\begin{array}{l}e 0.06 \\
(2.3)\end{array}$ & 1.91 & 0.47 & 2.13 & & \\
\hline $\begin{array}{l}\text { Covernment Inveatment } \\
\text { deflator }\end{array}$ & $\begin{array}{r}-0.40 \\
(1.3)\end{array}$ & $\begin{array}{r}0.10 \\
(3.1)\end{array}$ & $\begin{array}{r}0.16 \\
(6.0)\end{array}$ & $\begin{array}{l}0.28 \\
\text { (I) }\end{array}$ & & $\begin{array}{l}80.06 \\
(2.3)\end{array}$ & 1.43 & 0.68 & 1.92 & & \\
\hline
\end{tabular}

Sweden (Sample - 1973I-1985II; lag - 1 for import and 6 for domestic cost; laboux cost share - 0.75)

\begin{tabular}{|c|c|c|c|c|c|c|c|c|c|c|}
\hline $\begin{array}{l}\text { Private coneumption } \\
\text { deflator }\end{array}$ & $\begin{array}{r}0.79 \\
(2.2)\end{array}$ & $\begin{array}{r}0.24 \\
(3.8)\end{array}$ & $\begin{array}{r}0.09 \\
(1.8)\end{array}$ & $\begin{array}{l}0.25 \\
\text { (I) }\end{array}$ & $\begin{array}{l}20.09 \\
(2.2)\end{array}$ & 1.56 & 0.35 & 1.88 & & \\
\hline $\begin{array}{l}\text { Gorernment non-wage } \\
\text { consumption deflator }\end{array}$ & $\begin{array}{r}1.53 \\
(2.9)\end{array}$ & $\begin{array}{l}0.25 \\
\text { (I) }\end{array}$ & $\begin{array}{r}0.21 \\
(2.4)\end{array}$ & $\begin{array}{l}0.29 \\
\text { (I) }\end{array}$ & $\begin{array}{l}80.09 \\
(2.2)\end{array}$ & 2.69 & 0.60 & 2.00 & & \\
\hline $\begin{array}{l}\text { Residential con- } \\
\text { etruction deflator }\end{array}$ & $\begin{array}{r}0.71 \\
(0.4)\end{array}$ & $\begin{array}{r}0.14 \\
(3.2)\end{array}$ & $\begin{array}{r}0.05 \\
(0.8)\end{array}$ & $\begin{array}{l}0.31 \\
\text { (I) }\end{array}$ & $\begin{array}{l}20.09 \\
(2.2)\end{array}$ & 1.05 & 0.82 & 1.57 & 1.20 & $\begin{array}{r}0.87 \\
(7.2)\end{array}$ \\
\hline $\begin{array}{l}\text { Buednees investment } \\
\text { deflator }\end{array}$ & $\begin{array}{r}0.12 \\
(0.2)\end{array}$ & $\begin{array}{r}0.32 \\
(5.5)\end{array}$ & $\begin{array}{r}0.03 \\
(1.2)\end{array}$ & $\begin{array}{l}0.31 \\
\text { (I) }\end{array}$ & $\begin{array}{l}80.09 \\
(2.2)\end{array}$ & 1.53 & 0.60 & 2.59 & & \\
\hline $\begin{array}{l}\text { Government invertment } \\
\text { deflator }\end{array}$ & $\begin{array}{r}0.48 \\
(1.5)\end{array}$ & $\begin{array}{r}0.18 \\
(4.9)\end{array}$ & $\begin{array}{r}0.04 \\
(2.1)\end{array}$ & $\begin{array}{l}0.31 \\
(I)\end{array}$ & $\begin{array}{l}20.09 \\
(2.2)\end{array}$ & 1.01 & 0.49 & 1.35 & & \\
\hline
\end{tabular}


Table 5 (continued)

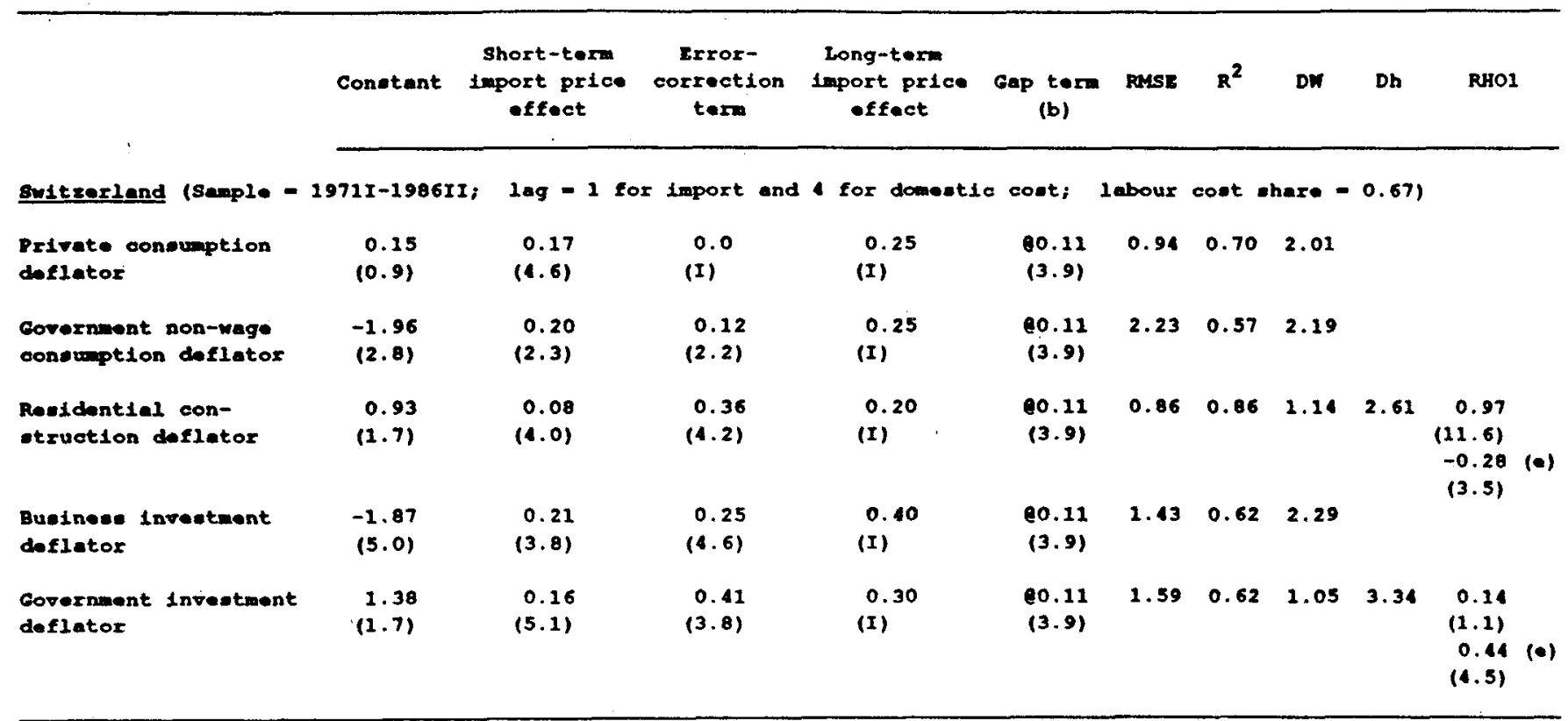

a) The dependent variables are the growth in domestie demand deflators. The derivation of the government non-wage deflator 1s explained in the text. Equations are estimated by MiNDIS on coasonally-adjueted cemi-annual date. In a few countries, for instance in Belgium, eeri-annual values are interpolated ennual numbers. T-otatietice appear in parentheses below coefficients. A coefficient with an (I) below ie lmposed, a coefficient with at the ide 1 s constrained across quations.

b) The gap variable is a two-semeater moving average for all the countries.

c) Includes a term for an adminietered component of consurer prices with a weight of 0.27 .

d) Includes a term for quaternary services and domestic gas deliveries with weights of 0.28 and 0.07 reapectively In the private coneumption deflator, and for domestic gas deliveries with a weight of 0.06 in the government non-wage consumption deflator.

-) RHO2. 
Note to Table 5

Country-specific dummy variables in the price equations (Values - 1 unless otherwise indicated)

\begin{tabular}{|c|c|c|c|c|}
\hline Australia & PCGNW & $\begin{array}{l}1973 \mathrm{I} ;-1 \text { in } 1973 \mathrm{II} \\
1977 \mathrm{I}, 1978 \mathrm{I} ;-1 \text { in } 1977 \mathrm{II}, 1978 \mathrm{II} \\
1981 \mathrm{I} ;-1 \text { in } 1981 \mathrm{II} \\
1982 \mathrm{I} ;-1 \text { in } 1982 \mathrm{II} \\
1985 \mathrm{I}, 1985 \mathrm{II}, 1986 \mathrm{I}, 1986 \mathrm{II}\end{array}$ & $\begin{array}{r}-3.19 \\
-2.87 \\
-5.29 \\
6.67 \\
-9.22\end{array}$ & $\begin{array}{l}2.0 \\
2.7 \\
3.6 \\
4.6 \\
7.1\end{array}$ \\
\hline Austria & PCGNW & $\begin{array}{l}1971 \mathrm{I}, 1972 \mathrm{I}, 1973 \mathrm{I} ;-1 \text { in } 1971 \mathrm{II}, 1972 \mathrm{II}, 1973 \mathrm{II} \\
1974 \mathrm{I}, 1975 \mathrm{I}, 1976 \mathrm{I} ;-1 \text { in } 1974 \mathrm{II}, 1975 \mathrm{II}, 1976 \mathrm{II} \\
1978 \mathrm{I} ;-1 \text { in } 1978 \mathrm{II} \\
1981 \mathrm{I}, 1982 \mathrm{I} ;-1 \text { in } 1981 \mathrm{II}, 1982 \mathrm{II} \\
1983 \mathrm{I} ;-1 \text { in } 1983 \mathrm{II} \\
1985 \mathrm{I} ;-1 \text { in } 1985 \mathrm{II} \\
1971 \mathrm{I}, 1972 \mathrm{I} ;-1 \text { in } 1971 \mathrm{II}, 1972 \mathrm{II}\end{array}$ & $\begin{array}{r}8.15 \\
-7.28 \\
6.57 \\
2.31 \\
-1.98 \\
0.82 \\
2.99\end{array}$ & $\begin{array}{r}16.0 \\
15.7 \\
8.3 \\
4.4 \\
2.5 \\
1.1 \\
7.2\end{array}$ \\
\hline Belgium & PCGNW & $1974 \mathrm{II}, 1975 \mathrm{I} ;-1$ in $1974 \mathrm{I}, 1975 \mathrm{II}$ & 2.52 & 2.7 \\
\hline Finland & $\begin{array}{l}\text { PIB } \\
\text { PIG }\end{array}$ & $\begin{array}{l}1972 \mathrm{I}, 1973 \mathrm{I}, 1974 \mathrm{I} ;-1 \text { in } 1972 \mathrm{II}, 1973 \mathrm{II}, 1974 \mathrm{II} \\
1975 \mathrm{I}, 1976 \mathrm{I}, 1977 \mathrm{I}, 1978 \mathrm{I} ;-1 \text { in } 1975 \mathrm{II}, 1976 \mathrm{II}, \\
1977 \mathrm{II}, 1978 \mathrm{II} \\
1972 \mathrm{I} ;-1 \text { in } 1972 \mathrm{II} \\
1975 \mathrm{I} ;-1 \text { in } 1975 \mathrm{II} \\
1977 \mathrm{I}, 1978 \mathrm{I} ;-1 \text { in } 1977 \mathrm{II}, 1978 \mathrm{II} \\
1974 \mathrm{I}, 1975 \mathrm{I} ;-1 \text { in } 1975 \mathrm{II}, 1975 \mathrm{II} \\
1975 \mathrm{I} ;-1 \text { in } 1975 \mathrm{II}\end{array}$ & $\begin{array}{r}4.10 \\
-3.46 \\
-2.95 \\
-7.18 \\
1.38 \\
2.58 \\
4.60\end{array}$ & $\begin{array}{l}4.9 \\
2.7 \\
4.2 \\
1.7 \\
3.3 \\
5.4\end{array}$ \\
\hline Greece & $\begin{array}{l}\text { PCGNW } \\
\text { PIB }\end{array}$ & $\begin{array}{l}1986 I I \\
1973 I I \\
1974 I I\end{array}$ & $\begin{array}{r}13.64 \\
12.47 \\
-11.24\end{array}$ & $\begin{array}{l}5.0 \\
4.3 \\
3.8\end{array}$ \\
\hline New Zealand & PCGNW & $\begin{array}{l}1975 \mathrm{I}, 1976 \mathrm{I}, 1977 \mathrm{I} ;-1 \text { in } 1975 \mathrm{II}, 1976 \mathrm{II}, 1977 \mathrm{II} \\
1985 \mathrm{I}, 1986 \mathrm{I} ;-1 \text { in } 1985 \mathrm{II}, 1986 \mathrm{II}\end{array}$ & $\begin{array}{r}1.45 \\
-3.37\end{array}$ & $\begin{array}{l}1.2 \\
2.3\end{array}$ \\
\hline Norway & PIB & $\begin{array}{l}1973 \mathrm{I}, 1974 \mathrm{I} ;-1 \text { in } 1973 \mathrm{II}, 1974 \mathrm{II} \\
1975 \mathrm{I} ;-1 \text { in } 1975 \mathrm{II} \\
1984 \mathrm{I}, 1985 \mathrm{I} ;-1 \text { in } 1984 \mathrm{II}, 1985 \mathrm{II} \\
1986 \mathrm{I} ;-1 \text { in } 1986 \mathrm{II} \\
1985 \mathrm{II}\end{array}$ & $\begin{array}{r}-2.91 \\
23.45 \\
-3.54 \\
8.02 \\
17.72\end{array}$ & $\begin{array}{r}2.4 \\
10.9 \\
2.9 \\
3.8 \\
8.2\end{array}$ \\
\hline Spain & PCGNW & 1986 II & 10.90 & 4.0 \\
\hline Sweden & $\begin{array}{l}\text { PCGNW } \\
\text { PIB }\end{array}$ & $\begin{array}{l}1980 \mathrm{I}, 1981 \mathrm{I} ;-1 \text { in } 1980 \mathrm{II}, 1981 \mathrm{II} \\
1982 \mathrm{I}, 1983 \mathrm{I}, 1984 \mathrm{I} ;-1 \text { in } 1982 \mathrm{II}, 1983 \mathrm{II}, 1984 \mathrm{II} \\
1978 \mathrm{I}, 1979 \mathrm{I}, 1980 \mathrm{I} ;-1 \text { in } 1978 \mathrm{II}, 1979 \mathrm{II}, 1980 \mathrm{II}\end{array}$ & $\begin{array}{r}-3.19 \\
3.76 \\
-2.57\end{array}$ & $\begin{array}{l}2.7 \\
4.0 \\
4.8\end{array}$ \\
\hline Switzerland & PCGNW & $\begin{array}{l}1974 \mathrm{I} ;-1 \text { in } 1974 \mathrm{II} \\
1976 \mathrm{I}, 1977 \mathrm{I} ;-1 \text { in } 1976 \mathrm{II}, 1977 \mathrm{II} \\
1978 \mathrm{I} ;-1 \text { in } 1978 \mathrm{II} \\
1980 \mathrm{I}, 1981 \mathrm{I} ;-1 \text { in } 1980 \mathrm{II}, 1981 \mathrm{II}\end{array}$ & $\begin{array}{r}-3.25 \\
-2.04 \\
5.15 \\
3.29\end{array}$ & $\begin{array}{l}2.5 \\
2.3 \\
4.1 \\
3.6\end{array}$ \\
\hline
\end{tabular}

PCGNW Government non-wage consumption deflator

PIH Residential construction deflator

PIB Business investment deflator

PIG Government investment deflator 
Table 6

Wage/price block simulations

(Belgian model)

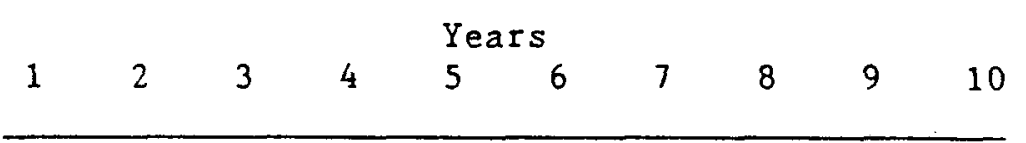

1. Sustained increase in the level of

all cost components (a)

$\begin{array}{llllllllllll}\text { Labour cost } & 1.0 & 1.0 & 1.0 & 1.0 & 1.0 & 1.0 & 1.0 & 1.0 & 1.0 & 1.0 \\ \text { Capital cost } & 1.0 & 1.0 & 1.0 & 1.0 & 1.0 & 1.0 & 1.0 & 1.0 & 1.0 & 1.0 \\ \begin{array}{l}\text { Import cost } \\ \begin{array}{l}\text { Private consumption } \\ \quad \text { deflator }\end{array}\end{array} & 1.0 & 1.0 & 1.0 & 1.0 & 1.0 & 1.0 & 1.0 & 1.0 & 1.0 & 1.0 \\ & 0.4 & 0.9 & 1.1 & 1.2 & 1.1 & 1.1 & 1.1 & 1.0 & 1.0 & 1.0\end{array}$

2. Sustained ex ante shock to the level

of wages $(a)$; costs and prices endogenous

\begin{tabular}{|c|c|c|c|c|c|c|c|c|c|c|}
\hline Wage rate & 1.1 & 1.5 & 1.9 & 2.3 & 2.6 & 2.8 & 2.8 & 2.9 & 2.8 & 2.8 \\
\hline Import prices & 01 & 0.2 & 0.3 & 0.4 & 0.5 & 0.5 & 0.5 & 0.5 & 0.5 & 0.5 \\
\hline $\begin{array}{l}\text { Private consumption } \\
\text { deflator }\end{array}$ & 0.2 & 0.5 & 1.0 & 1.3 & 1.7 & 1.8 & 1.9 & 1.9 & 1.8 & 1.7 \\
\hline
\end{tabular}

3. Sustained import price level shock (a);

other costs and prices endogenous

$\begin{array}{lllllllllll}\text { Import prices } & 1.0 & 1.0 & 1.0 & 1.0 & 1.0 & 1.0 & 1.0 & 1.0 & 1.0 & 1.0 \\ \begin{array}{l}\text { Wages rate } \\ \begin{array}{l}\text { Private consumption } \\ \text { deflator }\end{array}\end{array} & 0.0 & 0.3 & 0.4 & 0.6 & 0.7 & 0.8 & 0.9 & 1.0 & 1.0 & 1.0 \\ & 0.2 & 0.4 & 0.5 & 0.7 & 0.8 & 0.9 & 0.9 & 1.0 & 1.0 & 1.0\end{array}$

4. One-period shock to the gap term (b);

costs and prices endogenous

$\begin{array}{lllllllllll}\text { Import prices } & 0.0 & 0.0 & 0.0 & 0.0 & 0.1 & 0.1 & 0.0 & 0.0 & 0.0 & 0.0 \\ \begin{array}{l}\text { Wages rates } \\ \begin{array}{l}\text { Private consumption } \\ \text { deflator }\end{array}\end{array} & 0.0 & 0.1 & 0.1 & 0.2 & 0.2 & 0.2 & 0.2 & 0.1 & 0.1 & 0.1 \\ & 0.1 & 0.1 & 0.2 & 0.2 & 0.2 & 0.2 & 0.2 & 0.1 & 0.1 & 0.1\end{array}$

a) By 1 per cent of the baseline level.

b) By 1 percentage point of the baseline level. 


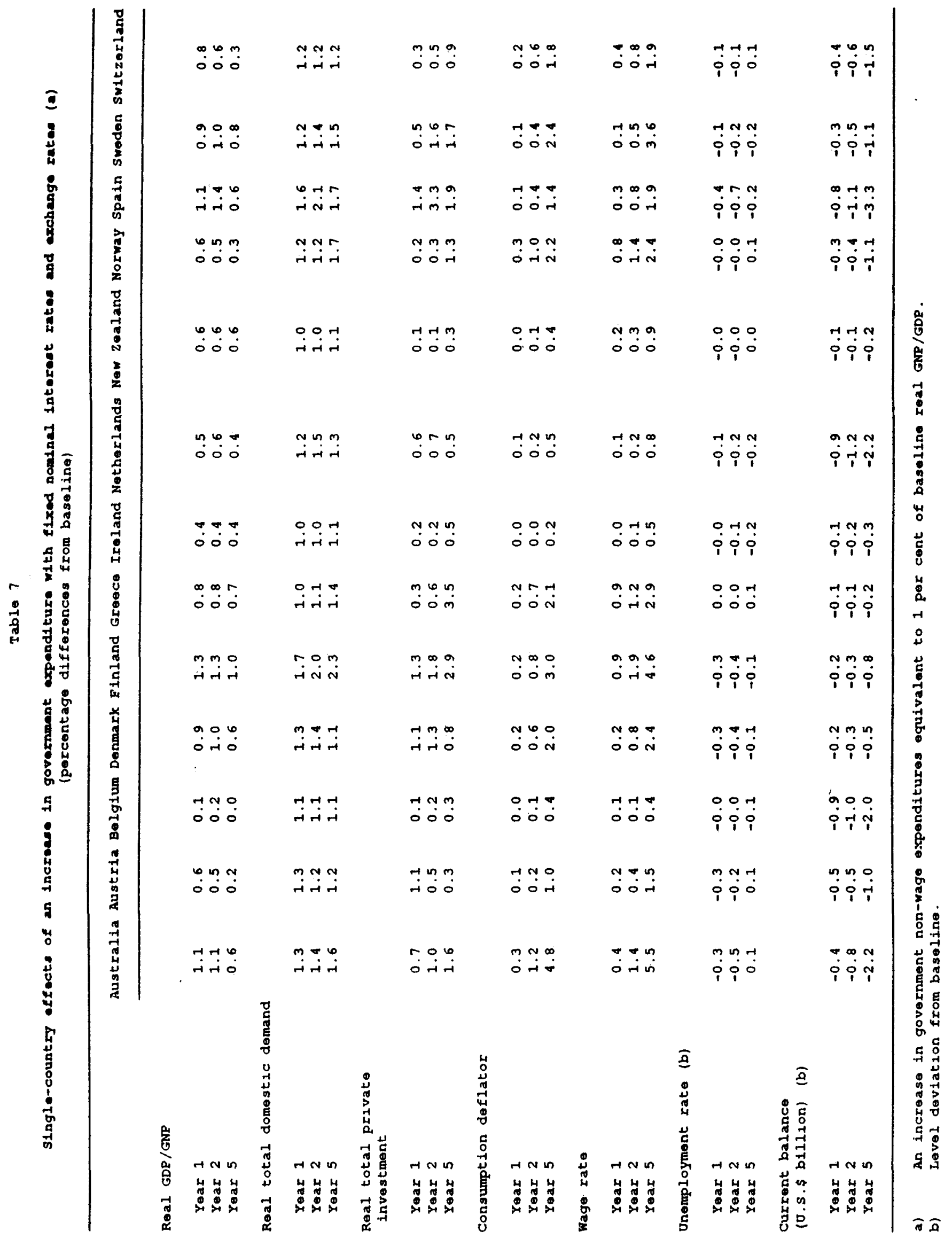




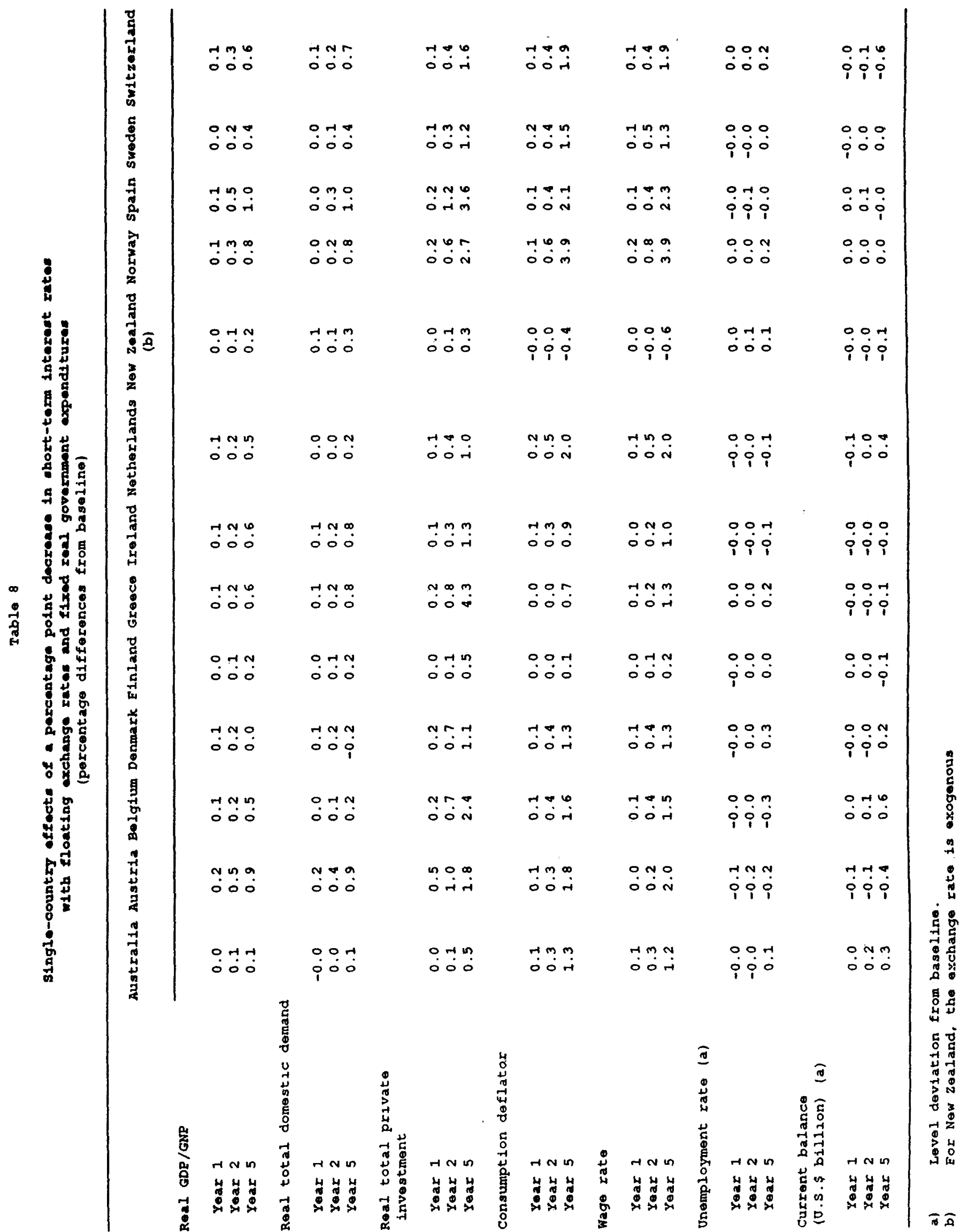




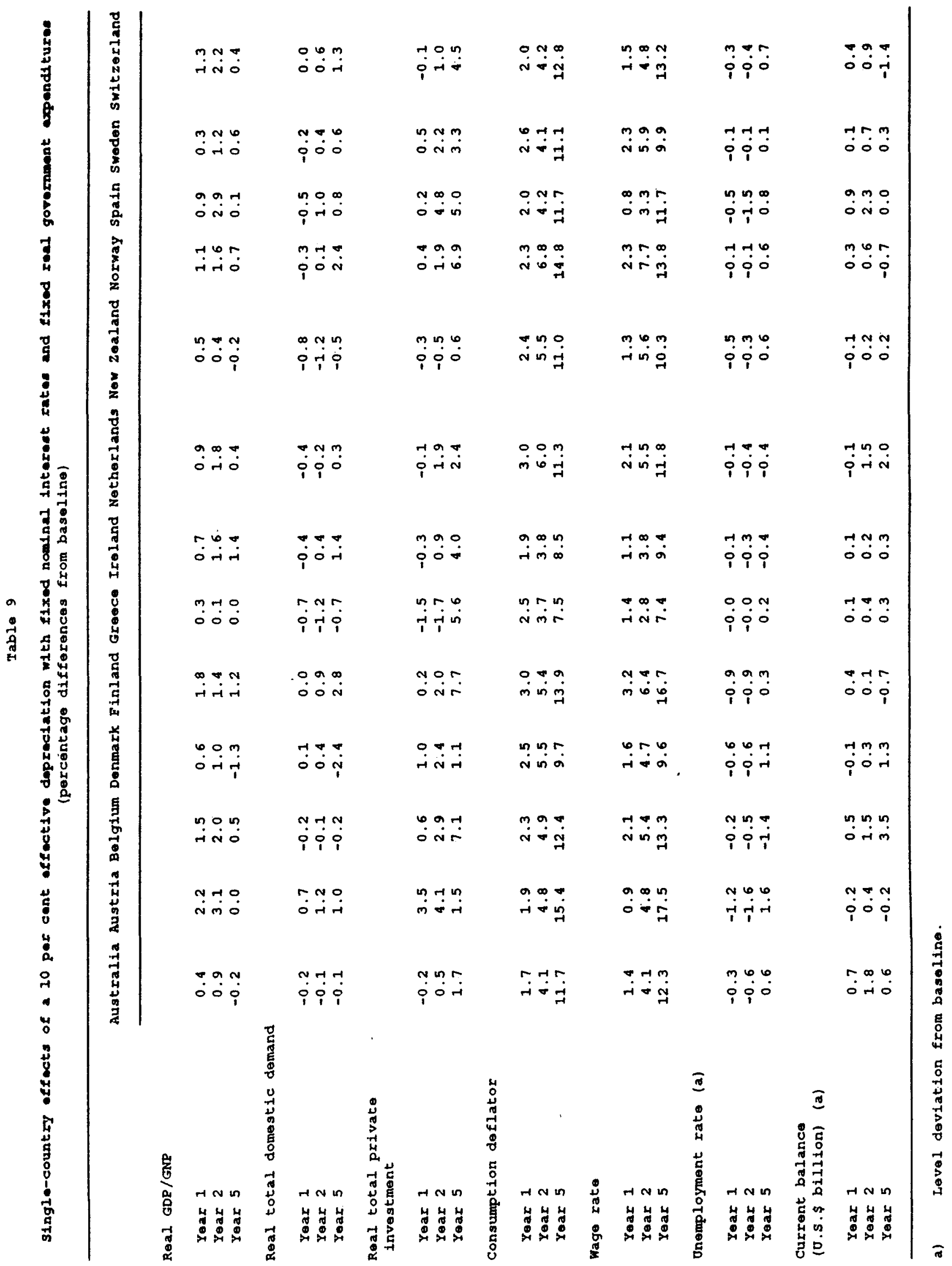




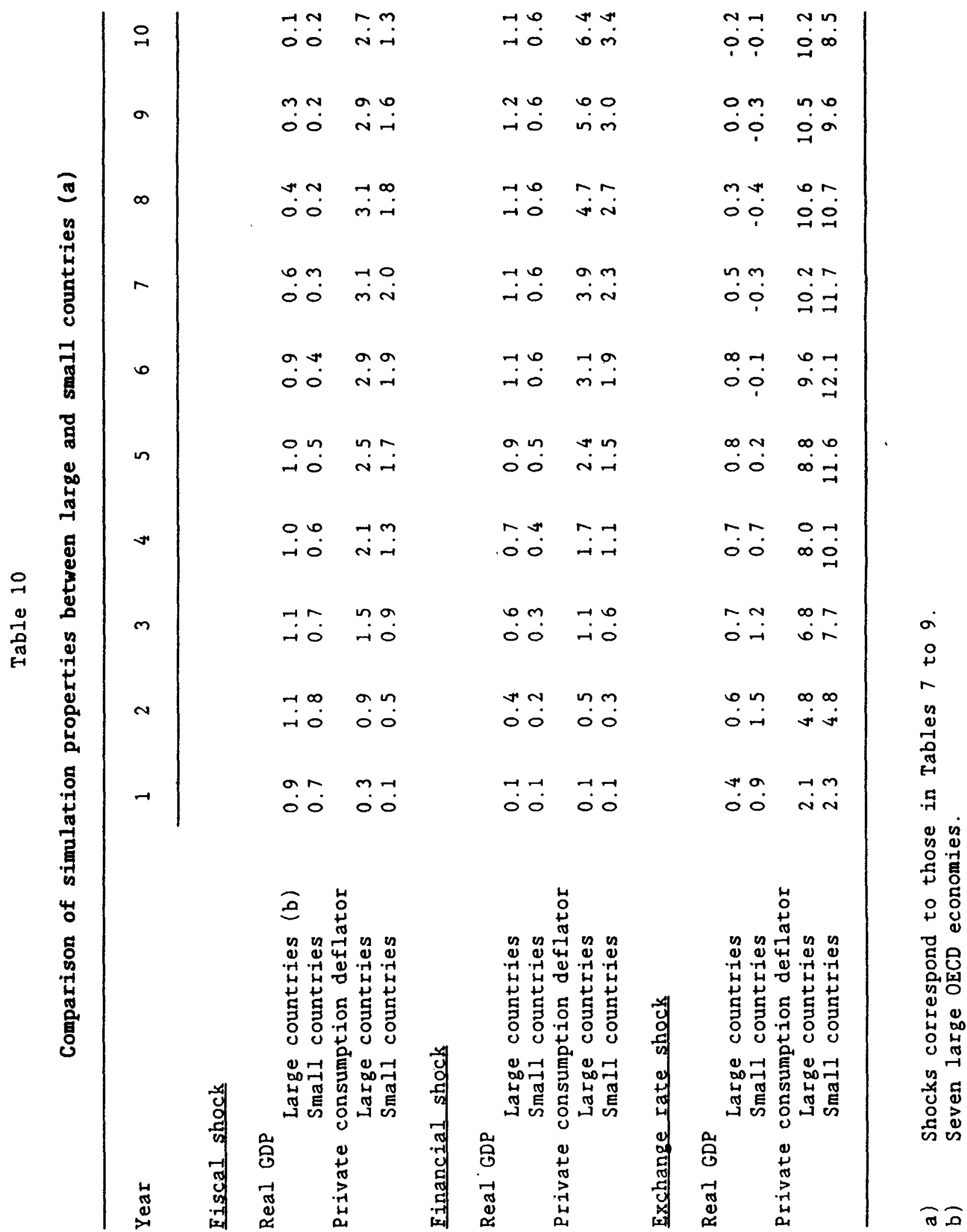


ECONOMIC AND STATISTICS DEPARTMENT

\section{WORKING PAPERS}

In April 1983, the Economics and Statistics Department initiated a new series of economic studies entitled ESD Working Papers.

The following titles have been circulated:

1. Use of Demand Elasticities in Estimating Energy Demand (out of print) Utilisation des élasticités de la demande dans l'estimation de la demande de I'énergie

\section{Axel Mittelstädt}

2. Capital, Energy and Labour Substitution: The Supply Block in OECD Medium-Term Models

Substitution du capital, de 1'énergie et du travail : le bloc de 1 'offre dans les modèles à moyen terme de 1'OCDE (épuisé)

\section{Patrick Artus}

3. Wage Formation in France: Sectoral Aspects (out of print) Formation des salaires en France : aspects sectoriels (épuisé)

\section{Patrick Artus}

4. Service Lives of Fixed Assets (out of print)

Durée de vie utile des actifs fixes (épuisé)

Derek Blades

5. Resource Prices and Macroeconomic Policies: Lessons from Two 0il Price Shocks

Prix des ressources naturelles et politique macro-économique : les enseignements de deux chocs pétroliers (épuisé)

John Llewellyn

6. Output Responsiveness and Inflation: An Aggregate Study Souplesse de la production et inflation : étude globale

David T, Coe and Gerald Holtham 
7. The Determinants of Exchange Rate Movements (out of print)

Les déterminants des mouvements des taux de change (épuisé)

Graham Hacche

8. Simulated Macroeconomic Effects of a Large Fall in 0il Prices (out of print)

Simulation des effets macro-économiques d'une forte baisse des prix pétroliers

Flemming Larsen and John Llewellyn

9. Medium-Term Financial Strategy: The Co-ordination of Fiscal Monetary Policy (out of print)

Stratégie financière à moyen terme : 1a coordination des politiques monétaire et budgétaire (épuisé)

Jean-Claude Chouraqui and Robert Price

10. Price Dynamics and Industrial Structure: A Theoretical and Econometric Analysis (out of print)

Dynamique des prix et structure industrielle : une analyse théorique économétrique (épuisé)

David Encaoua (with collaboration from Paul Geroski and Riel Miller)

11. Evidence on Income Distribution by Governments (out of print)

L'Action exercée par l'Etat sur la redistribution du revenu

Peter Saunders

12. Labour Force Participation: An Analysis with Projections

Taux d'activité : analyse et projections

James H. Chan-Lee

13. The Demand for Money and Velocity in Major OECD Countries (out of print)

La demande de monnaie et la vitesse de circulation dans les grands pays de I'OCDE

A. Blunde11-Wignal1, M. Rondoni and $\mathrm{H}$. Ziegelschmidt

14. The Conduct of Monetary Policy in the Current Recovery La conduite de la politique monétaire dans la phase actuelle de reprise économique

Paul Atkinson and Jean-Claude Chouraqui 
15. Structural Budget Deficits and Fiscal Stance (out of print)

Déficits budgétaires structurels et orientation de la politique budgétaire (épuisé)

Patrice Muller and Robert W.R. Price

16. Monetary Policy in the OECD INTERLINK Model

La politique monétaire dans le modèle INTERLINK

A. Blunde11-Wigna11, M. Rendoni, H. Ziegelschmidt and J. Morgan

17. Real Gross Product in OECD Countries and Associated Purchasing Power Parities (out of print)

Produit brut réel et parités de pouvoir d'achat dans les pays de 1 'OCDE (épuisé)

Peter Hill

18. The OECD Compatible Trade and Production Data Base (out of print) Base de données compatibles sur le commerce et la production de 1 'OCDE

Derek Blades and Wendy Simpson

19. Nominal Wage Determination in Ten OECD Economies

Détermination des salaires nominaux dans dix économies de 1'OCDE

David T. Coe and Francesco Gagliardi

20. Profits and Rates of Return in OECD Countries

Profits et taux de rendement dans les pays Membres de 1'OCDE

James $H$. Chan-Lee and Helen Sutch

21. Real Interest Rates and the Prospects for Durable Growth

Taux d'intérêt réels et perspectives de croissance durable

Paul Atkinson and Jean-Claude Chouraqui

22. Energy Prices: Trends and Prospects

Les prix de l'energie : évolution et perspectives

Axel Mittelstädt 
23. Changes in the Composition of Output and Employment

Changements dans la composition de la production et de l'emploi

Axel Mittelstädt and Francoise Correia

24. Labour Market Flexibility and External Price Shocks

Flexibilité du marché du travail et chocs extérieurs sur les prix

E. Klau and A. Mittelstädt

25. Discrepancies Between Imports and Exports in OECD Foreign Trade Statistics (out of print)

Ecart entre les importations et les exportations dans les statistiques du commerce extérieur de 1'OCDE

Derek Blades and Marina Ivanov

26. Aggregate Supply in INTERLINK: Model Specification and Empirical Results

John HeIliwe11. Peter Sturm. Peter Jarrett and Gérard Salou

27. Commodity Prices in INTERLINK

Gerry Holtham. Tapio Saavalainen, Paul Saunders and Helen Sutch

28. Exchange Rates and Real Long-Term Interest Rate Differentials:

Evidence for Eighteen OECD Countries

David T. Coe and Stephen S. Golub

29. Method of Calculating Effective Exchange Rates and Indicators of Competitiveness (out of print)

\section{Martine Durand}

30. Public Debt in a Medium-Term Context and its Implications for Fiscal Policy.

Jean-Claude Chouraqui, Brian Jones and Robert Bruce Montador

31. The OECD Compatible Trade and Production Data Base 1970-1983

Anders Brodin and Derek Blades 
32. The Formulation of Monetary Policy: A Reassessment in the Light of Recent Experience

Paul Atkinson and Jean-Claude Chouraqui

33. Mécanismes de transmission et effets macro-économiques de la politique monétaire en France : les principaux enseignements econométriques

Marc-Olivier Strauss-Kahn

34. Pure Profit Rates and Tobin's $q$ in Nine OECD Countries James H. Chan-Lee

35. Wealth and Inflation Effects in the Aggregate Consumption Function G.H. Holtham and H. Kato

36. The Government Household Transfer Data Base

Rita Varley

37. Internationalisation of Financial Markets: Some Implications for Macroeconomic Policy and for the Allocation of Capital

Mitsuhiro Fukao and Masaharu Hanazaki

38. Tracking the US External Deficit, 1980-1985: Experience with the OECD INTERLINK Mode1

Pete Richardson

39. Monetary Policy in the Second Half of the 1980s: How Much Room For Manoeuvre?

Kevin Clinton and Jean-Claude Chouraqui

40. Tax Reform in OECD Countries: Economic Rationale and Consequences Bob Hagemann. Brian Jones and Bruce Montador

41. A Revised Supply Block for the Major Seven Countries in INTERLINK Peter Jarrett and Raymond Torres 
42. OECD Economic Activity and Non-Oil Commodity Prices: Reduced-Form Equations for INTERLINK

Gerald Holtham and Martine Durand

43. Import and Export Price Equations for Manufactures

Richard Herd

44. Price Determination in the Major Seven Country Models in INTERLINK U1rich Stiehler

45. International Investment-Income Determination in INTERLINK: Models for 23 OECD Countries and Six Non-OECD Regions

David T. Coe, Richard Herd and Marie-Christine Bonnefous

46. Recent Developments in OECD's International Macroeconomic Model Pete Richardson

47. A Review of the Simulation Properties of OECD's INTERLINK Model Pete Richardson

48. The Medium-Term Macroeconomic Strategy Revisited Jean-Claude Chouraqui. Kevin Clinton and Robert Bruce Montador

49. Are Commodity Prices Leading Indicators of OECD Prices?

Martine Durand. Sveinbjörn Blöndal

50. Private Consumption, Inflation and the "Debt Neutrality Hypothesis" The case of Eight OECD Countries

Giuseppe Nicoletti

51. The Effects of Monetary Policy on the Real Sector: An overview of Empirical Evidence for Selected OECD Economies

Jean-Claude Chouraqui. Michae1 Drisco11 and Marc Olivier Strauss-Kahn 
52. The So-Called "Non-Economic" Objectives of Agricultural Policy L. Alan Winters

53. Alternative Solution Methods in Applied General Equilibrium Analysis

Richard G. Harris

54. Tests of Total Factor Productivity Measurement

\section{A. Steven Englander}

55. Quantifying the Economy-Wide Effects of Agricultural Policies: A General Equilibrium Approach

Jean-Marc Burniaux. Erançois Delorme. Ian Lienert. John P. Martin and Peter Hoeller

56. On Aggregation Methods of Purchasing Power Parities

J.R. and M. Cuthbert

57. An Internationa1 Sectoral Data Base for Thirteen OECD Countries E.J.M. Meyer-zu-Schlochtern

58. Empirical Research on Trade Liberalisation with Imperfect Competition: A Survey

\section{J. David Richardson}

59. Eliminating the US Federal Budget Deficit by 1993: the Interaction of Monetary and Fiscal Policy

R. Herd and B. Ballis

60. Compatible Trade and Production Data Base: 1970-1985

Claude Berthet-Bondet. Derek Blades and Annie Pin

61. Ageing Populations: Implications for Public Finances Robert P. Hagemann. Giuseppe Nicoletti 
62. The Economic Dynamics of an Ageing Population: the Case of Four OECD Economies

Alan J. Auerbach, Laurence J. Kotlikoff Robert P. Hagemann, Giuseppe Nicoletti

63. Modelling Housing Investment for Seven Major OECD Countries Thomas Egebo and Ian Lienert

64. Revised Groupings for non-OECD Countries in OECD's macroeconomic mode1 INTERLINK

Paul O'Brien. Laure Meuro. Arthur Camilleri

65. A Post Mortem on OECD Short-Term Projections from 1982 to 1987

Byron Ballis

66. Potential Output in the Seven Major OECD Countries

Raymond Torres and John P. Martin

67. Saving Trends and Behaviour in OECD Countries

Andrew Dean. Martine Durand. John Fallon and Peter Hoeller

68. The Impact of Increased Government Saving on the Economy

Richard Herd

69. The Information Content of the Terms Structure of Interest Rates: Theory and Practice

Frank Browne and Paolo Manasse

70. On the Sequencing of Structural Reforms

Sebastian Edwards

71. Modelling Business Sector Supply for the Smaller OECD Countries Raymond Torres. Peter Jarrett and Wim Suyker 
72. The Role of Indicators in Structural Surveillance

73. The Saving Behaviour of Japanese Households Kenichi Kawasaki

74. Industrial Subsidies in the OECD Economies Robert Ford and Wim Suyker

75. Measuring Industrial Subsidies: Some Conceptual Issues Professor Neil Bruce

76. The Dollar Position of the Non-U.S. Private Sector, Portfolio Effects, and the Exchange Rate of the Dollar

Bixio Barenco

77. Monetary Policy in the Wake of Financial Liberalisation Adrian Blunde11-Wigna11, Frank Browne and Paolo Manasse

78. Indicators of Fiscal Policy: A Re-examination Jean-Claude Chouraqui, Robert P. Hagemann, Nicola Sartor

79. Suggestions for a New Set of Fiscal Indicators Professor 0livier Blanchard (MIT and NBER)

80. Fiscal Indicators Professor Edward Gramlich. University of Michigan

81. Financial Liberalisation and Consumption Smoothing Adrian Blunde11-Wigna11. Frank Browne. Stefano Cavaglia

82. Economics in the Environment: a Survey of Issues and Policy Options Jon Nicolaisen. Peter Hoeller 
83. Exchange Rate Policy in Advanced Commodity-exporting Countries: The case of Australia and New Zealand

Adrian Blunde11-Wigna11. Robert G. Gregory, Australian National University

84. WALRAS -- a Multi-sector, Multi-country Applied General Equilibrium Model for Quantifying the Economy-wide Effects of Agricultural Policies: a Technical Manual

Jean-Marc Burniaux. François Delorme, Ian Lienert and John P. Martin

85. Simulating the OECD INTERLINK Model under Alternative Monetary Policy Rules

Pete Richardson 